MESÂHA'NIN KISA TARİHİ VE İLK MÜSTAKIL TÜRKÇE MESÂHA KITTABI: EMRÎ ÇELEBÎ'NIIN MECMAU'L-GARÂİB FI'L-MESÂHA ADLI ESERI

\title{
Elif Baga
}

İstanbul Medeniyet Üniversitesi

elif.baga@medeniyet.edu.tr

orcid: 0000-0003-2951-2563

\begin{abstract}
Öz
İlm-i mesâha, İslam Medeniyeti matematikçilerinin kendilerinden önceki medeniyetlerden tevarüs ettikleri matematik birikimini iki temel nesne yani, sayı/aded/süreksiz nicelik ve büyüklük/mikdâr/sürekli nicelik etrafında şekillendirmeleri neticesinde meydana gelen dört asli disiplinden biridir. Diğer disiplinlerden hesap ve cebir aded, hendese ise mikdâr etrafında dönerken ilm-i mesâha her iki nesneyi de ilgilendirmesi bakımından farklı bir konuma sahiptir ve bu niteliğiyle o, kendi usûlünü besleyen teorik temeli yanında "ölçerek hesaplama" ana ilkesiyle mühendislik, mimari, şehircilik, askeri teknoloji ve çeşitli sanatların asli aracı konumundadır.
\end{abstract}

* Benzer bir başlık, Osmanlı Bilimi Sempozyumu'nda (Sakarya, 2019) sunulan, ancak yayınlanmayan bir bildiride kullanılmıştır. Bu makale ise TÜBİTAK 1003-Öncelikli Alanlar kategorisinde desteklenen 119K740 numaralı ve "Osmanlı Klasik Dönem Matematiğindeki Alan ve Hacim Hesaplama Çalışmalarının Konumu, Nitelikleri, Değeri ve Seyri ile Bunların Mimari ve Askeri Sahalardaki Yansımaları" adlı proje kapsamında tamamlanmıştır. 
İslam Medeniyetinin tüm ilmi birikimini devralan Osmanlı Medeniyetinin, ilm-i mesâha alanındaki çalışmaları da sahiplendiği ve kendi ihtiyaç, talep ve yönelimleri çerçevesinde devam ettirdiği muhakkaktır. 15. ve 16. asırlardan itibaren mütedavil ilim dili olan Arapça yanında Türkçe matematik telifleri de ortaya çıkmıştır. Araştırmalara göre günümüze ulaşabilen en erken tarihli müstakil Türkçe mesâha kitabı Mecmau 'l-Garâib fi'l-Mesâha bu ilk olma özelliği dolayısıyla bu çalışmanın konusunu oluşturur. Ancak eserin tanıtımından önce bir arka plan sağlamak için genel anlamda Osmanlı matematik geleneği özelde de mesaha geleneği özetlenmiştir. Makalede eserin tanıtımının yapılabilmesi için tarihsel ve matematiksel değerlendirme yöntemi kullanılmıştır. Makalenin dönemin mesâha ilmindeki seviyesini tespit ederek Osmanlı Medeniyeti matematik tarihi çalışmalarına katkı sağlaması yanında eserin alanda bilinen ilk Türkçe çalışma olması hasebiyle Türk dili araştırmalarına da kaynak olması hedeflenmektedir.

Anahtar kelimeler: Osmanlı, matematik, mesâha, uygulamalı geometri, Emrî Çelebi. 


\section{Giriş}

Osmanlı, tarih sahnesinde zaman bakımından uzun, coğrafi bakımdan da geniş bir yer kaplamasına, buna bağlı olarak birçok ilim, sanat ve edebiyat dalı ile ilgili tarihsel çalışmalarda onu yok saymanın büyük bir boşluk yaratmasına binaen yaklaşık bir asırdır dünya genelinde pek çok araştırmaya konu olmuştur ve olmaktadır. Bu araştırmalarda siyaset, bürokrasi, yönetim mekanizmaları, diplomasi, ekonomi, vergilendirme, askeri yapılanma gibi devletin işleyişini ve askeri bakımdan gücünü ele alan konuların öne çıktığı görülür. ${ }^{1}$ Buna karşılık mimari, süsleme sanatları ve tıp gibi zanaat yönü de bulunan uygulamalı alanlar hariç tutulduğunda ${ }^{2}$ başta matematik ve astronomi olmak üzere fizik, kimya ve biyoloji gibi riyâzî ve tabii ilimlerin Osmanlı topraklarındaki serüvenini konu alan çalışmalar yok mesabesindedir. ${ }^{3}$ Bu alandaki çalışmalar, özel uzmanlık gerektirmesinden dolayı dünya tarihi veya Osmanlı tarihi araştırmalarına değil de bilim tarihi araştırmalarına dahil edilse sonuç değişmez: Osmanlı bilimi hakkındaki çalışmalar, bilim tarihi çalışmalarının tamamına oranlandığı zaman ortaya çıkan sayı, üç kıtaya yayılmış, altı yüz yıl ayakta kalmış bir medeniyetin tüm üretimleri dikkate alındığında hak ettiği değerin çok altındadır ve Osmanlının ilmi etkinliğini ortaya koymaktan çok uzaktır. Bu durumun başta konjonktürel, siyasi, sosyal, psikolojik olmak üzere pek çok muhtemel sebebi başka çalışmaların konusudur ve burada atılması gereken ilk adım vakıayı tespittir. Vakıa, binlerce sayfa makale ve kitaba konu olan Osmanlı iktisadi düzeninin, hukuk sisteminin, imar ve şehircilik anlayışının, mimarisinin ve askeri mühendisliğinin sadece zanaatla veya ödünç alınmış ilkel bir teorik veriyle açıklanamayacağıdır. Öyleyse tüm bunların zeminindeki

1 Virginia H. Aksan, "What's Up in Ottoman Studies?", Journal of the Ottoman and Turkish Studies Association, 1/1-2 (2014), 3-21.

2 Bunlardan, özellikle günümüzde maddi varlığını sürdürmesi, yani göz önünde olması dolayısıyla, mimari ve süsleme sanatları hakkında hatırı sayılır miktarda çalışma mevcutsa da çoğunluğu, bu alanlar için gerekli nazari altyapıdan ziyade zanaat tarafına vurgu yapar.

3 Bu duruma metafizik, tabiiyyât, mantık ve diyalektik gibi felsefi ilimlerin Osmanlı topraklarındaki serüveni hakkındaki araştırmaların yetersizliği de eklenmelidir. Bununla birlikte son yıllarda alanda öncü ve ufuk açıcı bazı çalışmaların yayınlanmış olması umut vericidir. İki örnek için bkz. Ömer Mahir Alper, Osmanlı Felsefesi: Seçme Metinler, (İstanbul: Klasik Yayınları, 2015); Khaled el-Rouayheb, Islamic Intellectual History in the Seventeenth Century, (New York: Cambridge Univesity Press, 2015).

Dîvân

$2021 / 2$ 
nazari temeli ortaya çıkarmak icab eder, aksi takdirde bina sağlam olmayacağı gibi neye benzeyeceği de belirsizdir, zira nasıl olduğu bilinmeyen bir temel üzerine inşa edilmektedir. İkinci adım, Osmanlı coğrafyasında yazılmış, okunmuş, tercüme edilmiş, yeniden üretilmiş, kullanılmış ve yaygınlaşmış tüm yazma ve basma eserlerin envanterini çıkarıp içerik, dönem ve dil gibi çeşitli kriterlere göre ayrıntılı tasnifini yapmaktır. ${ }^{4}$ Üçüncü adım, tespit ve tasnif edilen eserlerin içeriklerini anlama ve anlamlandırma, son adım da hem her bir ilim dalının tarihsel süreç boyunca değişimini hem de üstten bir bakışla nazari ve ameli ilimlerin ilişkiler ağı içerisinde bir bütün olarak aktivitesini değerlendirmektir. Eserlerin envanterini çıkarma hususunda henüz alınacak çok yol olsa da diğer taraftan tespit edilen teliflerin, bir konuda ilk olma, yaygınlık, kapsayıcılık gibi kriterlere göre oluşturulan öncelik sıralamasına uygun biçimde içerik analizine tabi tutulması, alandaki gecikmişliği bir miktar telafi edecektir. Osmanlı coğrafyasında üretilen ilk müstakil Türkçe mesâha kitabının tanıtımı da bu meyanda değerlendirilmelidir. Ancak kitabın içerik tanıtımının anlamlandırılabilmesi için dahi "Osmanlı" ve "matematik" kelimeleri yan yana geldiğinde zihinde bir tasavvurun oluşması, buna ilave olarak matematiğin bir dalı olarak mesahanın konumunun ortaya çıkarılması gerekir. Dolayısıyla eserin önemi, değeri, seviyesi ve içeriğini ortaya koyabilmek, içinde bulunduğu Osmanlı mesaha geleneğinin ne ifade ettiğini ve nerede durduğunu göstermeyi gerektirir. Bunun için de Osmanlı mesahasının Osmanlı matematik geleneğini oluşturan diğer alanlar, ilm-i aded, hesap, cebir ve hendese ile birlikte nasil konumlandığını ortaya koymak zorunludur.

Öyleyse şimdi "Osmanlı klasik döneminde matematik ilimlerin genel çerçevesi nedir?" diye sorulabilir. Bu soru bağlamında akla ilk olarak "hangi tarih" ve "hangi matematik" soruları gelir. Tarihten başlamak gerekirse "Osmanlı klasik dönem" ifadesi Osmanlı' yı farklı açılardan inceleyen birçok disiplinin ortaklaşa kullandığı bir tabirdir. İster küçük bir şehir devleti ister büyük bir imparatorluk

4 IRCICA bünyesinde telif edilen Osmanlı Matematik Literatürü Tarihi I-II, Osmanlı Astronomi Literatürü Tarihi I-II, Osmanlı Tabii ve Tatbiki Bilimler Literatürü Tarihi I-II, Osmanlı Tıbbi Bilimler Literatürü Tarihi I-II, Osmanlı Askerlik Literatürü Tarihi I-II, Osmanlı Musiki Literatürü Tarihi ve Osmanlı Coğrafya Literatürü Tarihi I-II bu konuda öncü ve alandaki tek çalışmalardır. 1997-2008 yılları arasında yani on bir senede yedi farklı ilim dalına ait literatür ortaya çıkarılmış, ancak o tarihten bugüne on yılı aşkın sürede herhangi benzer bir çalışma ortaya çıkmadı̆̆ı gibi bazı eksik ve hataların giderileceği yeni baskılar da yapılmamıştır. 
olsun bir topluluğun ilim, sanat, edebiyat, ekonomi, siyaset ve savunma gibi alanların tamamında aynı dönemlerde aynı seviyede gelişim veya değişim göstermesi hem rasyonel olarak hem de tarihi tecrübenin gösterdiği üzere mümkün değildir. Öyleyse her bir alan kategorisi, kendi sahasında yapılan araştırmaların sonuçlarından beslenerek bir dönemlendirmeye tabi tutulmal, bunun neticesinde sadece birbirine benzer olan alanlar için genel bir dönemlendirmeye girişilmelidir. Aksi takdirde herhangi bir kategori için yapılan dönemlendirmeyi diğerlerine de teşmil etme ve dolayısıyla tarihi gerçekleri yanlış kurgulama hatasına düşülür. ${ }^{5}$

Yukarıda söylenenler bağlamında matematik ilimler açısından Osmanlı medeniyetinde nasıl bir dönemlendirme yapılabilir? Bunun için matematik alanında altı asır boyunca yapılan üretimlerin tespit ve tahlilinin büyük oranda tamamlanmış olması gerekir ancak halihazırda ve yakın gelecekte böyle bir vaziyet mümkün görünmediğinden şu an, mevcut eserlerin sadece tespit edilebilenleri esas alınmak kaydıyla ${ }^{6}$ kesin olmayan bir dönemlendirme yapı-

5 Bu hataların en yaygını, siyaset ve ekonomi bağlamında Halil İnalcık'ın Osmanlı İmparatorluğu Klasik Çağ(1300-1600) adlı eseriyle özdeşleşen dönemlendirmenin Osmanlı'ya dair her disiplinde geçerli kabul edilmesidir. Klasik çağ dönemlendirmesi hakkında daha fazla bilgi için bkz.: Halil İnalcık, Osmanlı İmparatorluğu Klasik Çağ (1300-1600), çev. Ruşen Sezer, (İstanbul: YKY, 2007). Özellikle kamuoyunda yaygın olan diğer bir yanlış algı ise sadece toprak kazanma-kaybetme ile doğru orantılı olarak meydana getirilen ve eğitim-öğretim müfredatında ciddi bir etkiye sahip olan "kuruluşyükselme-duraklama-gerileme-dağılma” şeklindeki bir dönemlendirmenin ilimden sanata, edebiyattan mimariye kadar her sahada geçerli olduğu anlayışıdır. Mehmet Genç’in ifadesine göre bu dönemlendirme kavramları, peşin ve çoğu kere yanıltıcı olabilecek istikametlere yönlendiren olumsuz değer yargıları ile yüklü kavramlardır ve söz konusu dönemde olup bitenleri anlamlandırma, çevçeveleme ve açıklama bakımından elverişsiz olarak nitelendirilebilir. Daha fazla bilgi için bkz. Mehmet Genç, Osmanlı Imparatorluğunda Devlet ve Ekonomi, (İstanbul: Ötüken Yayınlar, 2013), 31-38. Söz konusu dönemlendirmenin sadece askeri başarı açısından değerlendirildiğinde bile ciddi problemler taşıması bir yana başka alanlara teşmil edildiğinde ne denli yanlış anlama, yaklaşım ve kabullere götürdüğü ile ilgili olarak bkz. Erol Özvar, "Osmanlı Tarihini Dönemlendirme Meselesi ve Osmanlı Nasihat Literatürü”, Divan: Disiplinlerarası Çalışmalar Dergisi (Aralık 1999), 135-151. Osmanlı tarih yazımında gerileme paradigmasına karşı duruş etrafında dönemlendirme meselesini çeşitli tarihçiler gözünden okumak için bkz. Mustafa Armağan vd., Osmanlı Tarihini Yeniden Yazmak Gerileme Paradigmasının Sonu, (İstanbul: Timaş Yayınları, 2014)). Son olarak İslam düşünce tarihi bağlamında İslam Medeniyetinin XIV asrı için yeni bir dönemlendirme önerisi için bkz. İbrahim Halil Üçer (ed.), İslam Düşünce Atlası, (Konya: Konya Büyükşehir Belediyesi Kültür Yayınları, 2017).

6 Ekmeleddin İhsanoğlu vd., Osmanlı Matematik Literatürü Tarihi, IRCICA, İstanbul 1999, c. I-II. 
labilir. Buna göre XIV.-XVIII. asırlar arası, "klasik dönem", XVIIIXIX. asırlar arası klasik ve yenileşme arasında "geçiş dönemi" ve XIX.-XX. asırlar arası da "yenileşme dönemi" olarak isimlendirilebilir. Klasik dönem, matematiksel düşünme tarzında kökten bir dönüşümün yaşanmadığı, mevcut asli ilkelerin korunarak gelişim ve uyarlamanın devam ettiği, geçiş dönemi, klasik olanın ilkeler düzeyinde yavaş yavaş dönüşümünün yaşandığı, yenileşme ise harici unsurların da tesiriyle artık yeni bir matematik yapma tarzının ortaya çıktığı dönem olarak tarif edilebilir. Matematik ilimler bağlamında "Osmanlı klasik dönemi”nin kısa açıklamasını müteakip "hangi matematik" sorusu sorulabilir.

Önce antik Yunan medeniyeti daha sonra da İslam medeniyeti ${ }^{7}$ düşünce geleneğinde üretilen ilim tasniflerine göre ${ }^{8}$ matematik, nazari ilimler kategorisinde tabii ilimler ile metafizik arasında konumlandırılır ve ilm-i aded (sayllar teorisi), hendese, ilm-i hey'et ve mûsikî dörtlüsünü ihtiva eder. İlk iki disiplin, bizzat matematik nesneleri, sürekli ve süreksiz nicelikleri konu edinirken, son iki disiplin sırayla gökcisimleri ile sesleri çeşitli vecihlerden inceler. Bunlar, salt matematik ilimleri dikkate değer bir oranda kullandıkları için matematiksel ilimler altında bulunurlar, ancak konuları icabı matematiğe ilave farklı uzmanlıklar gerektirirler. Yine aynı gerekçelerle bugün bilim tarihi çalışmaları altında ilm-i aded ve hendese matematik tarihinde incelenirken ilm-i hey'et, astronomi tarihi, mûsikî de mûsikî tarihinde incelenir. Tüm bu izahların ardından soruda yer alan "matematik ilimler" ifadesi, klasik ilimler tasnifinde matematik ilmi altındaki dörtlüden ilk ikisine ve o ikisinin nesnelerinin (sürekli ve süreksiz niceliklerin) farklı yönlerden incelenmesi neticesinde ortaya çıan hesap, cebir ve mesâha disiplinlerine karşılık gelir. Şimdi bu disiplinlerin XIV.-XVIII. asırlar arasında Osmanlı coğrafyasındaki genel resmine bakılabilir.

Coğrafi olarak Bağdat, Kahire-Şam, İran-Türkistan ve EndülüsMağrib havzalarında temsil edilen İslam Medeniyeti matematik geleneğinin tamamını farklı dönemlerde miras alan Osmanlı, zaman içerisinde bu havzalardaki matematik üretme tarzlarını

7 Bu kavram, İslam'ın hüküm sürdüğü topraklarda üretilen her türlü ilmi, sınâî ve kültürel birikimin tamamını ifade eder.

8 İslam düşünce geleneğinde ilimler tasnifinin Fârâbî, Gazzâli ve Kutbuddin Şirâzî özelinde ayrıntılı analizi için bkz. Osman Bakar, Classification of Knowledge in Islam, Islamic Text Society, 1998. Osmanlı dönemini de içine alacak şekilde çeşitli bilginlerden ilimler tasnifi örnekleri için bkz. Müstakim Arıcı (ed.), İlimleri Sınıflamak: İslam Düşüncesinde İlim Tasnifleri, (İstanbul: Klasik Yayınları, 2020). 
bünyesinde insicam ile bir araya getirerek "Osmanlı matematik geleneği” ni yaratmıştır. Bu geleneği öncesinden ayıran ve "Osmanlı matematik geleneği” diye bir adlandırmayı hak eden temel hususiyetleri, hızlı, kolay ve sınanabilir çözüm odaklı matematik üretme ilkesi uyarınca matematiğin farklı dallarını birbirlerine uygulama, bu dallar arasındaki bağları kuvvetlendirme ve matematikten her alanda maksimum fayda elde etme ideali için hep yeni yol ve yöntem arayışında olma şeklinde özetlenebilir. ${ }^{9}$

Mezkûr geleneğin alt disiplinlerine gelince, İslam medeniyeti matematik geleneğinin başlangıcından itibaren iki temel nesne yani, aded/sayı/süreksiz nicelik ve mikdâr/büyüklük/sürekli nicelik etrafında şekillenen matematik, asırlar boyunca bu iki nesnenin farklı konumlandırma, anlamlandırma, birleştirme, ayrıştırma gibi ameliyeleri ile faal bir yapı sergilemiştir. Osmanlı klasik döneme gelindiğinde bu faal yapı, "aded"in kullanımıyla ilm-i aded, hesap ve hisâbî cebir, "mikdâr"ın kullanımıyla hendese, her ikisinin kullanımıyla da mesâha disiplinlerinde dikkate değer bir literatür olușturmuștur. ${ }^{10}$

Klasik gelenekte matematiğe sayılardan ve bu sayıların kendileri ile birbirlerine nispetle özelliklerinden başlandığı için Osmanlı klasik dönemde matematik ilimleri ifade eden ilm-i aded, hesap, cebir, hendese ve mesâha beşlisine ilm-i aded ${ }^{11}$ ile başlamak uygun olur. ${ }^{12}$ Sayılar teorisi şeklinde ifade edilebilecek disiplinde sayı, tamsayı, kesirli sayı, rasyonel sayı, irrasyonel sayı, tek sayı, çift sayı, asal sayı kavramlarının tanım ve açıklamaları merkezi önemdedir. Bilhassa "sayı nedir", "sayı aynî mi yoksa zihni mi?" ve "1 sayıların ilkesi

9 “Osmanlı matematik geleneği” kavramsallaştırmasının daha büyük ölçekteki versiyonu "Osmanlı bilim geleneği” dir. Kendine has özellikleriyle döneminin diğer bilim sistemlerinden farklılaşması ve dolayısıyla "Osmanlı bilimi” şeklindeki bir kavramsallaştırmanın nasıl mümkün olduğu ile ilgili olarak bkz. Miri Shefer-Mossensohn, Osmanlı'da Bilim: Kültürel Yaratı ve Bilgi Alışverişi, çev. Kübra Oğuz, (İstanbul: Türkiye İş Bankası Kültür Yayınları, 2019).

10 Nasîruddin Tûsî, Tahrîru Usûli'l-Hendese ve'l-Hisâb, haz. İhsan Fazlığlu, (İstanbul: Yazma Eserler Kurumu Yayınları, 2012), 33-34.

11 Antik Yunan döneminde "Aritmetika", İslam Medeniyeti ilim geleneğinin ilk dönemlerinde ise "el-Aritmetîkî" diye isimlendirilmiştir. Bugün temel hesap işlemleri anlamında kullandığımız "aritmetik" ile karıştırılmamalıdir.

12 Burada bahsedilen beş temel matematik disiplini hakkında ayrı ayrı yazılan eserlerden ziyade bunların tamamını veya çoğunu ihtiva eden genel matematik kitabı formundaki teliflerde mezkûr sıralama görülebilir. Örnekler için bir sonraki paragrafta sayılan eserlere bakılabilir. 
mi yoksa sayı mı" soruları etrafında dikkate değer bir birikim oluşmuş ve temel ilkeler burada tartışıldığı için ilm-i aded matematiğin usûlü olarak görülmüştür. ${ }^{13}$ Bunlardan başka sayıların tek başına veya başka bir sayıyla birlikte bölünebilme kapasitelerinin incelenmesi, birbirlerinin bölenleri toplamı kadar olan sayı çiftleri (dost/ mütehâbbe sayılar), kendi bölenleri toplamına eşit sayı (mükemmel), bölenleri toplamından fazla sayı (zâid) ve eksik sayı (nâkıs) kavramlarını ortaya çıkarmıştır. Özellikle mükemmel sayılar ile dost sayı çiftlerinin tespiti problemi etrafında oluşan literatür, disiplinin önemli bir kısmını teşkil eder. İki veya daha fazla sayı arasında ortaklık/iştirak, girişkenlik/tedâhul ve farklılık/tebâyün ilişkilerinden hangisinin bulunduğu problemi de burada incelenen konular arasındadır. ${ }^{14}$ Yine ilm-i vefk (sihirli kareler) denilen ve bir kareyi küçük kare kutucuklara bölmeye ve bu kutucuklara yatay, dikey ve çapraz sütunların toplamı aynı çıkacak şekilde sayılar yerleştirmeye dayanan alan, ilm-i aded altına yerleştirilir. Mısır ilim havzasında yetişen Muhammed b. Ali Şebrâmellisî'nin (ö. 1623'ten sonra) Kitâbü'l-İrşâd li'l-'Im bi-havâssi'l-a'dâd'1 ile Selanik ve İstanbul'da yetişen Müneccimbaşı Ahmed Dede'nin (ö. 1702) Gâyetü'l-uded fì ilmi'l-aded'i mezkûr konuları ihtiva eden genel matematik kitaplarından farklı olarak alandaki müstakil çalışmalardandır.

Osmanlı matematik geleneğinin en temel dalı olan hesap ilmine gelince, literatürde dikkati çeken ilk husus, hendeseyi dışarıda

13 Bu meselelerin en yoğun biçimde tartışıldığı eserlerin başında Bahâeddin Âmilî̀nin (ö. 1622) Hulâsatü'l-hisâb'ı ve şerhleri gelir. Osmanlı'da telif edilen ve oldukça yaygın olarak kullanılan üç şerhi Ramazan b. Ebû Hüreyre el-Cezerî'nin (1665’te sağ) Hallü'l-Hulâsa liehli'r-riyâse adlı şerhi, Abdürrahîm b. Ebû Bekir b. Süleyman Mar'aşî’nin (ö. 1736) Şerhu Hulâsati'l-hisâb'ı ve Ömer Çellî̀nin Şerhu'l-Bahâiyye'sidir. Burada bir örnek olması açısından Ömer Çellî’nin şerhindeki mezkûr tartışmalar için bkz. Elif Baga, "XVII. ve XVIII. yy.'da Osmanlı Matematik Eğitiminin İzini Sürmek: Ömer El-Çellî’nin Bahâî Şerhi”, Keşf-i Kadîmden Vaz'-ı Cedîde: İslâm Bilim Tarihi ve Felsefesi, ed. İbrahim Özcoşar vd., (İstanbul: Divan Kitap, 2019), 279-281.

14 Osmanlı'da kullanılan ilm-i aded eserlerinin en kapsamlılarından biri olan İbn Fellûs adıyla meşhur İsmail b. İbrahim Mardînî'nin (ö. 1232) sayıların tasnifi ve özellikleri yanında 25 farklı sayı türünü açıkladığı telifi Kitâbü I'dâdi'l-isrâr fì esrâri'l-a'dâd'ını incelemek için bkz. Sonja Brentjes, "The First Seven Perfect Numbers and Three Types of Amicable Numbers in a Manuscript on Elementary Number Theory by Ibn Fallûs", Erdem, 4/11 (1989) 467-484. Türkçe çevirisi için bkz. Sonja Brenjes, “İbn Fellûs'un Elemanter Sayı Teorisi Üzerine Olan Bir Yazmasındaki İlk Yedi Mükemmel Sayı ve Dost Sayıların Üç Çeşidi”, çev. Melek Dosay, Erdem, 4/11 (1989), 485-500. 
bırakarak diğer disiplinlerin tamamının veya çoğunun "hesap kitabı" adı altında bir araya getirildiği bir telif türünün yaygınlaşmasıdır. ${ }^{15}$ Böyle bir uygulamanın muhtemel sebebi, kökeni kadim Hint matematiğine kadar götürülen "0'dan 9'a rakamlar" ve "ondalık konumsal sayılama” ile icra edilen iki katını alma, yarıya bölme, toplama, çıkarma, çarpma ve bölmeden oluşan altı temel işlem yanında oran-orantı, çeşitli derecelerden kök çıkarma ve üs alma işlemlerini içeren hesap ilminin diğer salt matematiksel disiplinler olan ilm-i aded, cebir ve mesahaya tatbikinin bir arada gösterilmek istenmesidir. Tatbik mefhumunu biraz daha somutlaştırmak gerekirse, sayılar teorisinde "dost" veya "mükemmel" sayıları bulabilmek, cebirde farklı denklem türlerini temel denklem formlarına dönüştürebilmek ve çözüme ulaşabilmek, mesâhada da iki veya üç boyutlu şekilleri belirli bir birim aracılığıyla ölçebilmek için hep hesaptan faydalanılır ve bu anlamda hesap, salt matematik ilimler içinde uygulama alanı çeşitliliğiyle en temel disiplindir. Aynı şekilde hem astronomi, optik, mûsikî ve mekanik gibi diğer riyâzî ilimler hem de tıp, eczacılık, kimya gibi tabiiyyât altındaki disiplinlerin ihtiyaçlarının karşılanmasında da en yaygın ve işlevsel olandır. Mezkûr telif türüne birkaç örnek vermek gerekirse, İlhanlılar himayesindeki İbnü'l-Havvâm'ın (ö. 1324) el-Fevâidu'l-Bahâiyye fi'lkavâidi'l-hisâbiyye'si ${ }^{16}$ ile Nizâmuddin Nisâbûrî'nin (ö. 1328'den sonra) eş-Şemsiyye fi'l-hisâb' ${ }^{1},{ }^{17}$ Cemâleddin Türkistânî'nin (ö. XIV. yy?) er-Risâletü'l-Alâ'iyye fi'l-mesâili'l-hisâbiyye'si, Osmanlılar himayesindeki Ali Kuşçu'nun (ö. 1474) Risâletü'l-Muhammediyye'si, Uluğ Bey himayesindeki Cemşîd Kâşî’nin (ö. 1429) Miftâhu'lhussâb' ', Osmanlılar himayesindeki Ali b. Velîb. Hamza Mağribî̀nin Tuhfetüll-a'dâd li-zevîr-rüsş ve's-sedâd' 1 ve Safeviler himayesindeki Bahâeddin Âmilî’nin (ö. 1622) Hulâsatü'l-hisâb’’ sayılabilir.

15 Bu vakıanın İslam Medeniyetinde matematik ilimleri dönemlendirme çabası etrafında tespiti için bkz. İhsan Fazlığlu, "Bir Diriltme, Güncelleme ve Düzeltme Girişimi olarak İslâm Medeniyetinde Matematik Bilimlerin Doğuşu”, İslam Düşünce Atlası, ed. İbrahim Halil Üçer, (Konya: Konya Büyükşehir Belediyesi Kültür Yayınları, 2017), c. I, 462.

16 Müellif ve eseri hakkında metin analizine dayanan ayrıntılı bilgiler için bkz. İhsan Fazlığlu, İbn el-Havvam ve Eseri el-Fevâid el-Bahâiyye fi el-Kavâidi el-Hisâbiyye Tenkitli Metin ve Tarihi Değerlendirme, İstanbul Üniversitesi, İstanbul 1993.

17 Müellif ve eseri hakkında metin analizine dayanan ayrıntılı bilgiler için bkz. Nizâmeddin Nîsâbûrî, Hesap Biliminde Kllavuz, Haz. Elif Baga, (İstanbul: Yazma Eserler Kurumu Yay., 2020).

Dîvân

2021/2 
Hesap ilminin hemen ardından hesâb-ı erkâm veya hesâb-ı kalem gibi isimlerle anılan Osmanlı muhasebe matematiğini zikretmek gerekir. Zira Osmanlı'nın iç dinamiklerinin de tesiriyle matematiğin bu alanında işlevsel ve faal bir yapının tesis edildiği ve geliştirildiği söylenebilir. Üç farklı kıtaya yayılmış geniş topraklarda hüküm sürerken devletin tüm gelirlerinin tek bir elde toplanması ve giderlerin buradan karşılanması çok sayıda gelir ve gider kalemi oluşturmaya bu da değişkenlerin artmasına ve hesabın çetrefilli hale gelmesine sebep olur. Bu zorluk içerisinde bir kuruşu dahi atlamadan dakik bir hesap yapmak için başta cebir olmak üzere farklı uygulamaları devreye sokma fikri, geniş ölçekte Osmanlı bilim geleneğinin dar ölçekte de Osmanlı matematik geleneğinin işlevsel ve uyarlayıcı yapısını hatırlatır.

Osmanlı muhasebe matematiği deyince Muhyiddin Mehmed b. Hacı Atmaca Kâtib'in (ö. 1494'ten sonra) Mecma' el-kavâid'i, Matrakçı Nasuh'un (ö. 1564) Cemâl el-kuttâb ve kemâl el-hussâb ile Umdet el-hussâb'ı ve Ali b. Veli b. Hazma Mağribî'nin (ö.1614) Tuhfet el-adâd li-zevîr-ruşd ve'l-sedâd' 1 ilk aşamada dile getirilmesi gereken eserlerdir. ${ }^{18}$

Bir ilim dalı olarak 9. asırda İslam Medeniyeti matematikçilerinin elinde doğup büyüyen cebir ilmi, riyâzî ilimlerin herhangi bir alanında karşılaşılan herhangi bir problemi kendine has teknikleri sayesinde kolay ve hızlı bir şekilde çözüme kavuşturma özelliğiyle İslam ve de Osmanlı matematik geleneklerinde çokça rağbet gören alanlardan biridir. Etkili ve uygulama açısından esnek yönü yoğun bir biçimde araştırmalara konu olmasını, bu da çeşitlenmeyi ve farklı yaklaşımların ortaya çıkmasını sağlamıştır. Harizmî̀nin (ö. 847'den sonra) halefleri, onun cebirini Elementler'in diliyle okuduklarında hendesî cebir, hendesî cebirdeki zayıf noktaları fark edip hesâb-ı hindî diliyle okuduklarında adedî/hisâbî cebir yaklaşımını meydana getirmişlerdir. Osmanlı matematik geleneğine gelince, cebir ilminin her yönden genişleme ve gelişmesine olanak tanıyan ikinci yaklaşım üzerine kurulmuştur. ${ }^{19}$ Bunun yanında

18Osmanlı muhasebe matematiğinin özellikleri, içeriği, konumlanışı ve eserleriyle ilgili ayrıntılı bilgi için bkz.: İhsan Fazlığlu, "Devlet'in Hesabını Tutmak: Osmanlı Muhasebe Matematiğinin Teknik İçeriği Üzerine”, Kutadgubilig Felsefe-Bilim Araştırmalart, 17, (Mart 2010), 165-178.

$19 \mathrm{Bu}$ iki farklı okumadan kaynaklanan iki farklı cebirsel yaklaşımın açıklamaları ile Osmanlı cebir geleneğinin arka planı ve temeli hakkında bkz. Elif Baga, "İslâm Matematik Tarihinde Hisâbî Cebir Geleneği ve IX./XV. Asırdaki Zirvesi: İbnü’l-Hâim'in el-Mümti‘ Adlı Eseri”, Nazariyat, 3/2 (Nisan 2017), 75-80. 
İslam Medeniyeti ilim geleneği boyunca cebir ilminin esnek yapısından en fazla Osmanlı matematik geleneğinde faydalanıldığı; muhasebeden mesâhaya, ferâizden astronomiye birçok alandaki cebir uygulamalarıyla maksada daha hızlı, kolay ve dakik biçimde ulaşıldığı söylenebilir. Yine bir taraftan ilmin kalbi sayılan cebirsel denklemler teorisi içerisindeki çözüm yöntemlerinin çeşitlendirildiği diğer taraftan da denklem çözümlerinde "illet" kavramı üzerinden "adedî ispat” Oluşan geniş literatürden birkaç örnek vermek gerekirse, Mısır matematik geleneğinin önde gelen ismi İbn Hâim, eserlerini ürettiği bölge (Mısır) vefatından sonra Osmanlı topraklarına katılsa da cebir dahil tüm telifleri üzerine en çok çalışma burada yapıldığından Osmanlı cebir tarihinde en önemli figürlerden biri sayılmalıdır. Zira manzum eseri el-Mukni' fi'l-Cebr ve'l-Mukâbele şerh ve haşiyeleriyle birlikte 100 'den fazla nüshaya sahiptir ve XIX. yüzyıla kadar yeni çalışmalara konu olmuştur. ${ }^{21}$ Kısaca el-Mukni, şerhi elMumti've muhtasarı el-Musri' üçlemesi XIV.-XV. asır Osmanlısının cebir külliyatını özetler. ${ }^{22}$ XVI ve XVII. asırlarda Takıyüddin Râsıd'ın (ö. 1580) Kitâbu'n-Nisebi'l-Müteșâkile fi'l-Cebr ve'l-Mukâbele'si ile Abdulmecid Sâmûlî'nin (ö. XVI. yy) er-Risâletü'n-Nâfia fi'lHisâb ve'l-Cebr ve'l-Hendese'si XVIII. asırda da Gelenbevî İsmail Efendi'nin (ö. 1791) Hisâbu'l-Küsûr adlı Türkçe telifi sıralanabilir.

Hendese, doğru, yüzey ve talimi cisim gibi sürekli nicelikleri konu edinen ve İslam Medeniyetindeki oluşumu büyük oranda Antik Yunan geometri mirasına dayanan alandır. Ancak Yunanca "geometria" isminin Arapçalaşmış bir ifadesi yerine Farsça "ölçme" anlamına gelen "endâze" kelimesinden türetilmiş “hendese”yi kabul etmeleri, ${ }^{23}$ ilmin başlangıç noktası dış kaynaklı olsa da ilerleyişinin iç dinamiklerle sağlanması yönünde bir eğilime işaret sayılabilir. Nitekim hızlı bir özümseme sürecinin ardından uygulamalı geometri için "mesâha" adını verdikleri özel bir alan tahsis etmeleri, ${ }^{24}$

20 Osmanlı klasik dönemde cebir ilminin serüveni için bkz. Elif Baga, Osmanlı Klasik Dönemde Cebir, (İstanbul: Marmara Üniversitesi, 2012).

21 Eserin tüm şerhleri, haşiyeleri ve bunların nüshaları hakkında ayrıntılı bilgi için bkz. Celal Şevki, el-Ulûmu'l-akliyye fi'l-manzûmâti'l-Arabiyye, Kuveyt: 1990, 268-283; Ekmeleddin İhsanoğlu vd., OMLT, c. I, s. LXVI-LXXI. ayrıntılı bilgiler için bkz. Elif Baga, a.g.m., 69-126.

23 Harizmi, Mefâtihu'l-Ulûm, thk. İbrahim Ebyari, Beyrut 1989, 225.

24Eldeki verilere göre en erken tarihli müstakil Arapça mesaha kitabı Harizmi'nin en önemli halefi Ebu Kamil'e aittir. Ancak Harizmi, bilinen ilk 
cebir ve hendese arasında sıkı bir bağ kurup hendese ve cebir dilinin karşılıklı birbirine çevrilerek her iki alanda ciddi adımlar atılması ve geniş bir literatür oluşturulması, hendesî teorileri optik ve hiyel ilimlerinde kullanarak bunları sağlam temeller üzerine inşa etmeleri ve Antik Yunan'da geometri içinde sıkışıp kalmış trigonometriyi ayrı bir ilim dalı olarak ortaya koymalar ${ }^{25}$ bu eğilimin en güzel kanıtıdır.

Osmanlı hendese geleneğine gelince, öncelikle İslam medeniyeti hendesî mirasına vurgu yapmak gerekir. Bunun hemen ardından İslam Medeniyetinde olgunluğa erişen Yunan geometrisinin Osmanlı'dan hemen önce başlayan "şukûk" literatürüyle eleştiri, "tahrir" ve "islah" projeleriyle de yeniden üretilip dönüştürülme sürecinin devam ettirildiği, şerh ve haşiye yazım türleriyle genişletildiği, medreselerde okutulmak suretiyle de yaygınlaştırıldığı söylenebilir. ${ }^{26}$ Buna ilave olarak bir taraftan hendese içerisinde hem tabiiyyât hem de ilâhiyyâta uzanan felsefi tartışmalar gerçekleştirmeleri diğer taraftan hendesî ispatı kelam gibi matematik dışı alanlarda da kullanmaları dikkate değerdir. Son olarak, mesâha ilminde alan ve hacim ölçümleri en doğru biçimde yapabilmek için hendesede üretilen formüllerin ve ispatlarının dakikleştirilmesi, Osmanlı klasik döneminde mimari, mühendislik, şehircilik ve görsel sanatlarda görülen mükemmelleşmenin gizli kahramanıdır. Klasik dönemde sıklıkla kullanılan eserlere gelince, Nasirüddîn Tusî'nin (ö. 1274) Tahrîru usûli'l-hendese'si, Esiruddin Ebheri'nin (ö. 1265 [?]) Islâhu Kitâbi'l-Ustukussât fi'l-hendese li-Öklîdisi'si, Muhyiddin Yahyâ b. Ebü'ş-Şükr Mağribî'nin (ö. 1283) Tahrîru usûli'l-hendese'si ve Kitâbüll-Üker'i, İbn Sertâk'in (ö. XIV. yy) elİkmâl fi'l-hendese'si ve Kadızâde'nin (ö. 1440'tan sonra) Şerhu Eşkâli't-te'sîs' i sayılabilir. ${ }^{27}$

cebir kitabının bir bölümünü mesâhaya ayırarak bu konuda da öncülük ettiği söylenebilir. İlgili bölüm için bkz. Rüşdî Râşid, Rıyâdiyyâtu'l-Harizmi: Te'sîs ilmi'l-Cebr, çev. Nikola Haris, Beyrut: 2010, 220-223.

25 Nasîruddin-i Tûsînnin tarihte ilk kez trigonometri konularını müstakil bir kitapta ortaya koyması ile ilgili bkz. https://mathshistory.st-andrews. ac.uk/Biographies/Al-Tusi_Nasir/

Dîvân

26 İhsan Fazlıoğlu, "Her Şey Merv'de Başladı: Aklî İlimlerin Tahrîri”, İslam Düşünce Atlası (Erişim 24 Ekim 2020): https://www.islamdusunceatlasi. org/pages/yenilenme-donemi/her-sey-merv-de-basladi-akl-ilimlerintahr-ri

27 Anadolu Selçukluları ve Osmanlı dönemlerinde üretilen hendese literatürü ve muhtevası hakkında ayrıntılı bilgi için bkz. İhsan Fazlığlu, "Hendese”, Türkiye Diyanet Vakfi İslâm Ansiklopedisi (DİA), 1998, c. XVII, 199-208. 


\section{Hesap ile hendese arasında: Adedî ve mikdârî bir ilim olarak mesâha}

Arapça “m-s-h” kökünden türeyen "mesâha” kelimesi bir araziyi bir ölçü birimiyle ölçmek anlamındadır ve İslam medeniyeti ilim geleneğinin başlangıcından itibaren bu adlandırmayla bağımsız bir ilim dalı olma yolunda emin adımlarla ilerlemiştir. İlm-i mesâha ise sürekli nicelikler olarak tanımlanan uzunluk, alan ve hacimleri hesaplama/ölçme yöntemlerini araştıran ilim dalıdır. Bu tarifte "sürekli nicelikler" kavramı ile "hesaplama/ölçme" eyleminin bir araya gelmesine dikkat çekilmelidir. Çünkü tarif, onun matematiğin iki temel nesnesi olan "aded" ve "mikdâr" 1 bünyesinde birleştirmesinden kaynaklanan özel konumuna işaret eder. Bu özel konumu yani bütünleştirici yapısı onu, diğerlerine nispetle çok daha fazla sayıda bilimin ve tarihinin bir parçası haline getirir. Eğer "insan"1 tarih boyunca ürettikleri üzerinden anlamlandıracaksak mesâhanın hem dünya tarihindeki hem de bilimler tarihindeki yerinin, dolayısıyla “insan”ı anlamadaki rolünün önemini vurgulamak gerekir. Dış dünyada insan elinin değdiği birçok yerde; kubbe, kemer, tonoz gibi mimari, geometrik bezeme ve mukarnas gibi süsleme sanatları, arsa/tarla ölçüm ve paylaşımı gibi hukukî, temel kazma, imar planı, kuyu açma, kanalizasyon yapımı gibi şehircilik, istihkâm oluşturma, tünel kazma, silah tasarımı gibi askeri mühendislik, dağ yüksekliği ve rakım belirleme gibi coğrâfî alanlarda mesahaya ait yapıları görmek mümkündür. Mesâhanın dış dünyadaki yansımalarına yapılan vurgu onun tamamen tatbiki bir ilim olduğu anlayışına yol açmamalıdır. Zira nazari veya amelî tüm ilimler en temel ilkelerini metafizikten alırken diğer ilkelerini, konusunu ve problemlerini tartışmak için her birinin kendi içinde nazarî bir alan oluşturması gibi mesâha da en temel kabul ve ispatları hendeseden alır, diğer gereklilikler "ilmi ölçüm” adı altında geniş bir literatür oluşturur, "ilmi ölçüm”ün tecessüme uygun hale getirilmesiyle yani üzerinde ittifak edilen birim veya birimlerle icra edilip dış dünyaya aktarıldığında "tatbiki ölçüm” ortaya çıkar. ${ }^{28}$ Mesâhanın mahiyetini kavrama imkanı -en azından bu çalışma sınırlarında- ancak telif edilen eserlerle elde edilebileceğinden daha çok ilmi ölçüm esas alınacaktır. 
Mesâha ilmine dair elimizdeki ilk veri Harizmi'nin tarihte bilinen ilk cebir kitabı Kitâbü'l-Cebr ve'l-mukâbele'nin mesâha bâbıdır. ${ }^{29}$ Burada Harizmi mesâhanın tarifiyle başlar ve birim kavramını zirâ‘ ölçü birimi üzerinden açıklar. Bunun hemen ardından şekillere geçer ve sırayla kare, dikdörtgen, üçgen ve eşkenar dörtgenin alanı ile dairenin çevresi ve alanını, daire parçasının alanının nasıl hesaplanacağını anlatır. Sonra sıra cisimlere gelir; dörtgen prizmalar, üçgen prizmalar ve dik silindir, dik koni, üçgen ve kare piramitin hacim ölçümlerini verir. Mesaha örneklerine geçmeden önce Pisagor teoreminin kanıtını ikizkenar dik üçgen örneği üzerinden gösterir. ${ }^{30}$

Mesâha bâbı altına konulan tek başlık olan "mesâha problemleri”nde Harizmi, yukarıda özet ve dağınık bir şekilde verdiklerini hem biraz daha sistematik hem de sayısal örnekler üzerinden açıklayarak ortaya koyar. Buna göre beş çeşit dörtgen vardır: kare, dikdörtgen, eşkenar dörtgen, paralelkenar ve yamuk. Yamuğun köşegen vasıtasıyla iki üçgene dönüştürülerek alan hesaplaması yapıldığını bildirdikten sonra üçgen ile ilgili örnekler ve açıklamalara geçiş yapar. Üçgenler dik, dar açılı ve geniş açılı olmak üzere üç çeşittir ve eşkenar, ikizkenar ve çeşitkenar üçgenlerin alan ölçümlerini de bu çeşitler altında inceler. Daha sonra daire alanı ile kesik piramidin yüzey alanı ve hacim hesaplamasını göstererek kenarları verilen ikizkenar üçgenin içine çizilmiş karenin kenar ölçüsünü istediği bir örnekle konuyu sonlandırır. ${ }^{31}$ Burada Harizmi'nin mesâha bâbının nispeten ayrıntılı bir şekilde aktarımının gerekçesi, mesâha başlığı taşıyan en erken tarihli kaynak olması yanında okuyucuya, sonraki dönemlerde üretilen mesâha eserlerinin içerikleriyle bu en erken tarihli mesâha verilerini karşılaştırma yapma imkanı sunmaktır. Bundan sonraki örnekler sadece müstakil mesâha eserlerinden verilirken ilk örneğin Harizmi’nin mesâha bâbından sunulması, yukarıdaki gerekçeyle yani mevcut en erken tarihli mesâha metni olmasıyla ilgilidir.

14

Dîvân

$2021 / 2$
29 Harizmi'den de geriye gitmek, onun kaynaklarına dönmek istenirse, Antik Mezopotamya, Mısır ve Yunan kaynaklarından uygulamalı geometriye dair konuları kendi görüşleriyle birlikte düzenleyip toparlayan bilgin İskenderiyeli Heron'dur (III. yy) ve eserinin adı da Metrica'dır. Daha fazla bilgi için bkz. İhsan Fazlığlu, "Mesâha”, Türkiye Diyanet Vakfi İslâm Ansiklopedisi (DIA), 2004, c. XXIX, 261-264.

30 Râşid, Rıyâdiyyâtu'l-Harizmi: çev. Nikola Haris, 220-223.

31 Râşid, Rıyâdiyyâtu'l-Harizmi, çev. Nikola Haris, 224-234. 
Harizmi'den yaklaşık 60-70 yll sonra onun en önemli haleflerinden Ebu Kamil Şuca' b. Eslem Mısrî (ö. 930) yaklaşık on beş varaklık başlangıç seviyesinde muhtasar bir müstakil mesâha risalesi kaleme almıştır. ${ }^{32}$ Kitâb fi'l-Misâha adlı eser altı başlıktan oluşur. Yer/ alan ölçümü babı adlı ilk başlıkta "sınaat" olarak nitelediği mesâha alanındaki bu risalesinde anlattığı kuralların ispatlarını neden sunmadığını gerekçelendirir ve ispatlar için Öklides'in Elemanlar'ını adres gösterir. Hemen ardından kare ve dikdörtgenle ilgili ölçümlere geçer. Risalenin diğer başlıkları dairelerin ölçüm hesabı babı, üçgenlerin ölçüm hesabı babı, cisimlerin hacim ve yüzey ölçümleri, kürenin ölçümü ve kirişleri bulma babıdır. ${ }^{33}$

Ebu Kamil'den yaklaşık 60-70 yıl sonra Ebu'l-Vefa Büzcânî (ö. 998), Kitâb fimâ yehtâcü ileyhi's-sâni' min a'mâli'l-hendese adlı uygulamalı geometri hakkında bir eser telif etmiştir. Her ne kadar Büzcânî eserini mesâha kitabı olarak nitelemese de isminden ve içeriğinden mesâha ilminde zanaatkarların çokça kullandığı konuların belirlenip müstakil eser halinde bir araya getirilmiş şekli olduğu söylenebilir. İçeriğine gelince, on üç babdan oluşan eserde sırayla cetvel ve pergel kullanımı, usûl/yöntem, eşkenar şekiller, dairesel şekiller, daire içinde yer alan şekiller, şekillerin etrafına çizilen daireler, birbirinin içine çizilen şekiller, üçgenlerin taksimi, dörtgenlerin taksimi, dörtgenlerin taksimi ve birleştirilmesi, çeşitkenar şekillerin taksimi, temas eden daireler ve şekillerin kü-

32Aslında müellif bundan başka Misâhâtü'l-Muhammes ve'1-Mu'aşşar adıyla sadece beşgen ve ongenin ölçümünü konu alan spesifik bir risâle kaleme aldıysa da mesâha ilminin genelini yansıtmaktan uzak olduğu için buraya dahil edilmemiştir. Eserin bir nüshası için bkz. Ebu Kamil Şucâ‘ b. Eslem Mısrî, Misâhâtü'l-Muhammes ve'1-Mu'aşşar, (Beyazıt Devlet Kütüphanesi, Merzifonlu Kara Mustafa Paşa, 379/2).Eserin Latince, İbranice, Almanca, İtalyanca ve bir kısmının da Rusça tercümesi bulunmasına rağmen Türkçe herhangi bir çalışmaya konu olmamıştır.

33 Ebu Kamil'in kirişlerle ilgili bab açması okuyucuya tuhaf gelebilir, ancak aslında bu başlık altında vermeye çalıştığı şey, dairenin çapı ile bu dairenin içine veya dışına çizilmiş üçgen, dörtgen veya düzgün çokgenlerin kenarlarının ilişkisini göstermektir. Bu da daha sonra Ebu'l-Vefa'nın eserinde ayrıntılı bir şekilde incelenen ve mimari ile görsel sanatlarda kullanılan ağırlık merkezi bulma, denge ve yüzey kaplama işlemlerini hatırlatır. Eserin tahkikli metni, İngilizce tercümesi ve matematiksel incelemesi için bkz. Jacques Sesiano, “Abu Kamil's Book on Mensuration", From Alexandria, Through Baghdad: Surveys and Studies in the Ancient Greek and Medieval Islamic Mathematical Sciences in Honor of J.L. Berggren, ed. Nathan Sidoli Glen Van Brummelen, Springer-Verlag, Berlin 2014, 359-408. 
reye taksimi anlatılır. ${ }^{34}$ Eserin mimari ve görsel sanatlar alanında uzmanlara hitap etmesinden dolayı tasnif ve işleyişi genel mesâha kitaplarıyla tam uygunluk göstermese de üçgenler, dörtgenler, çokgenler ve daire şeklinde benzer bir tasnif yapılması, ayrıca şekillerin genel özellik ve ölçümlerinden bahsedilmesi bir mesâha eseri olarak anılması için yeterlidir.

Büzcânî'den yaklaşık çeyrek asır sonra fakih, kelamcı ve matematikçi Abdülkahir Bağdadi (ö. 1037-38) tarafından Kitâb fi'l-misâha adlı eser telif edilmiştir. Çalışma genel mesâha kitaplarına özgü bir girişle başlar; ölçüm ya yüzeyde (iki boyutlu) ya da cisimdedir (üç boyutlu), yüzeyde ise ya bir çizgi ile ya da çizgilerle çevrelenmiştir. Eğer bir çizgi ise dairedir çok çizgi ise, üçgen, dörtgen, beşgen, altıgen ... şeklinde devam eder. Eğer dörtgen hem dik açılı hem de eşkenar ise kare, sadece dik açılı ise dikdörtgen, sadece eşkenar ise eşkenar dörtgendir, her iki şart da yoksa yamuktur. Üçgenler de benzer şekilde çeşitlendirilir ve tanımlanır. Genel başlıklar halinde eserin içeriğini özetlemek gerekirse, dörtgenler, üçgenler, daire ve daire parçaları, çokgenler, cisimler, şekillerin taksimi olarak sıralanabilir. Bağdadi, her bir şekil grubu altındaki şekillerin tek tek tanımlayıp kısaca açıkladıktan sonra örneklerle gösterimini yapar. Örnek olarak üçgenler bâbı altında dar açılı üçgen türü olarak eşkenar üçgeni veya dik açılı üçgenin bir türü olarak ikizkenar üçgeni inceler. Hem burada hem de daha sonraki mesâha eserlerinde şe-

34 Ebu'l-Vefa Büzcânî, Kitâb fìmâ yehtâcü ileyhi's-sâni 'min a'mâli’l-hendese, (İstanbul: Süleymaniye Kütüphanesi, Ayasofya, 2753), 1b-35a. Eserin Uppsala Üniversitesi Kütüphanesi, Tornberg koleksiyonu, 324 numarada kayıtlı diğer nüshasının tahrif edilip el-Hiyelü'r-Rûhâniyye ve'l-Esrâr etTab'iyye fi Dakâ'iki el-Eşkâl el-Hendesiyye adıyla Fârâbî’ye nispet edilmesi, hatta bunun da Mehmet Bayraktar tarafından Fârâbî'ye ait zannedilip Teknik Geometri adıyla tercüme edilmesi ve diğer tartışmalar hakkında bkz. Makram Haddad ve Aziz Doğanay, "Kitâb fìmâ Yehtâcü İleyhi's-Sâni' min A'mâli'l-Hendese Adlı Eserin Âidiyet Meselesi Üzerine”, Türk-İslam Medeniyeti Akademik Araștırmalar Dergisi 12/23 (Kış 2017), 139-152. Eserin özellikle mimari ve süsleme sanatlarında kullanımı ve böylece matematik ile sanat arasında kurduğu bağ açısından analizi için bkz. Alpay Özdural, "Mathematics and Arts: Connections between Theory and Practice in the Medieval Islamic World", Historia Mathematica 27/2 (Mayıs 2000), 171201. İslam mimarisinde geometrik bezemeyi Topkapı parşömeni temelinde ve Büzcânî'nin eseri ile ona Kemâleddin b. Yunus'un yazdığı şerhi arkaplanıyla anlatan bir çalışma için bkz. Gülru Necipoğlu, The Topkapi Scroll: Geometry and Ornament in Islamic Architecture, (USA: The Getty Center Publications, 1995). Büzcani'nin eserine Kemaleddin b. Yunus Şerhu A'mâli'l-Hendeseadıyla önemli şerh yazmıştır. Bkz. Kemaleddin b. Yunus, Şerhu A'mâli'l-Hendese (Meşhed 5357). 
kil ve cisimlerin tasnifindeki sıkı mantıksal örgü dikkat çeker, hatta bu durumun ilerleyen asırlarda daha ileri aşamalara taşındığı söylenebilir. ${ }^{35}$

İbn Heysem'in (ö. 1041) Kavl fî usûli'l-Misâha ${ }^{36}$ (Fatih 3439/14), Ebu'l-Hasan Eşarî Yemenî'nin (ö. 1100) Kitâbu't-Tuffâha fî İlmi'lMisâha (Ayasofya 4827) ve İsmail Mardini'nin (1194-1252) etTuffâha fi A'mâli'l-Misâha ${ }^{37}$ (Hasib Efendi 527) adlı müstakil mesâha eserleri dönemin diğer dikkat çeken çalışmalarıdır.

Oldukça hacimli bir eser olan Eşarî'nin Tuffâha'sı giriş ile on iki babdan oluşur ve verdiği ayrıntılı bilgilerle Bağdadi'ye nispetle daha gelişmiş bir görüntü çizer. Kısaca eserin içeriği giriş, dörtgenler, üçgenler, daire, dairevi şekiller (yaylar), beşgenler, beşgenlerin ölçümü, dörtgenlerle ilgili bir mesele, üçgenlerle ilgili bir mesele, daireyle ilgili bir mesele, şekillerin bölünmesi, üçgenlerin bölünmesi ve dairenin bölünmesi şeklinde verilebilir. Bu tasnif öncesi ve sonrasında telif edilen eserlere göre klasik iki boyutlu şekiller ile üç boyutlu şekiller ayrımının dışında kalması, bazı üç boyutlu şekillerin iki boyutlular altında fasıl başlıkları içinde verilmesi açısından farklılı arz eder. ${ }^{38}$

İsmail Mardini'den sonra yaklaşık iki buçuk asır boyunca müstakil mesaha kitabı günümüze ulaşmamıştır. Bu durumun öncelikli sebebi, hesap mesaha ve cebir konularını bir araya getiren genel matematik kitabı yazma geleneğinin etkili olmasıdır. Ayrıca, Osmanlı matematik literatüründe de bu geleneğin sürdürülmesi, Os-

35Abdülkâhir Bağdadi, Kitâb fi'l-misâha, (İstanbul: Süleymaniye Kütüphanesi, laleli, 2708/2), 99b-117a. Eserin tahkikli neşri ve değerlendirmesi, Bağdadi'nin bir diğer matematik eseri et-Tekmile fi'l-Hisâb ile yayınlanmıştır. Bkz. Abdülkahir Bağdadi, et-Tekmile fi'l-Hisâb ve Kitâb fi'l-misâha, thk. Ahmed Selim Saîdân, (Kuveyt: Ma'hedu'l-Mahtûtâti'l-Arabiyye,1985).

36İbn Heysem'in bu risalesi genel mesaha kitabından ziyade birkaç spesifik probleme cevap vermek için telif edilmiştir. O yüzden mesahanın geneli hakkında bilgi vermez. İbn Heysem'in bu risalesi ve dağ yüksekliğini ölçme konusunda başka bir risalesinin İngilizce tercümeleri ve matematiksel değerlendirmeleri için bkz. Roshdi Rashed, Ibn Al-Haytham's Theory of Conics, Geometrical Constructions And Practical Geometry, İng. çev. J. V. Field, Routledge, 2013, 469-568.

37 Bu risalenin yazma nüshaları yanında baskı nüshasının da bulunması, yoğun bir şekilde kullanıldığına işaret olabilir. Baskı nüshaları için bkz. Millet Ktp., Ali Emiri Arabi 4413 ve 4414.

38Eserin içeriği hakkında daha fazla bilgi için bkz. Süleymaniye Ktp., Ayasofya $4827,99 a-160 b$.

Dîvân

2021/2 
manlı klasik dönemine ait müstakil mesaha kitabı sayısının nispeten sınırlı kalmasının gerekçesi olarak görülebilir.

Çalışmanın sınırları gereğince ilk dönem örneklerini daha fazla uzatmadan Osmanlı' da yazılmış müstakil mesâha kitabı örneklerine geçilirse, makalenin konusu Mecmau'l-Garâib fi'l-Mesâha'dan yaklaşık bir asır önce Fâtih Sultan Mehmed döneminde Arapça olarak telif edilen ve kendisine sunulan müellifi meçhul $e l-\grave{l} k n \hat{a}^{\prime} f \hat{\imath}$ ilmi'l-misâha adlı kitap önemli çalışmalardan biridir. Divan katipleri ve muhasipleri düşünerek eseri telif ettiğini söyleyen meçhul müellif, imar faaliyetlerine atıf yaparak mimarları da hedef kitlesine eklediği düşünülebilir. Üç kısımdan oluşan eserin birinci kısmında yüzeylerin, ikinci kısmında cisimlerin mesâhası, üçüncü kısmında mesâha konusunda nâdir problemler ele alınır. İlk kısım yüzeysel şekilleri ihtiva eden beş bâbdan oluşur ve ilk bâbda müellif mukaddime başlığıyla mesahanın nokta, birlik, çizgi, yüzey, cisim, doğru, açı gibi temel terimleri, bilhassa da hakkında felsefi tartışmaların bulunduğu "nokta" ve "birlik" kavramları üzerinde durur. Diğer bâblarda da sırayla dörtgenler, üçgenler, daire ve dairevi şekiller, son olarak da çokgenlerin alan ölçümlerinden bahseder. İkinci kısım cisimsel şekilleri ele alır ve altı bâbda küp, koni, prizma, silindir, ezec-tâk ve kürenin nasıl meydana geldiğini, yüzey alanları ile hacim hesaplamalarını açıklar. Son kısım "nevâdir" başlığını taşır ve özellikle saray gibi yapıların yüzeylerinde karşılaşlan iç içe geçmiş şekilleri doğru oranlarla yerleştirme problemi ile kuyu kazılması, yapılan işin ücretinin hesaplanması, havuz problemi gibi sorular ve bunların cevaplarından oluşur. ${ }^{39}$

el-İknâ' adlı mesâha risalesinin ardından 16. asrın son çeyreğinde Emrî Çelebî tarafından telif edilen ve günümüze ulaşan en erken tarihli Türkçe müstakil mesâha kitabı olan Mecmau'l-Garâib fi'l-Mesâha' ya geçmeden müellif hakkında kısa bilgiler vermek uygun olacaktır.

\section{Divan edebiyatına adanmış bir ömür: Emrullah Edirnevi}

Tam adı Emrullah b. Ahmed b. Mahmûd Edirnevi olan müellifin 16. asır başlarında Edirne'de doğduğu ve büyüdüğü tahmin edilebilir. Tahsil hayatına dair herhangi bir bilgi yoktur. Kaynaklar-

39İ. Fazlığlu, Uygulamalı Geometrinin Tarihine Giriş, 58-64. 
daki bilgilere göre geçimini imâret kâtipliği ile sağlamış, bilhassa Edirne'de Yıldırım Bayezid Medresesinde bu görevi ifa etmiştir. Ancak bu memuriyette sürekli kalmadığı, bir süre sonra azledildiği ve bu yüzden maddi sıkıntılar yaşadığı ulaşan bilgiler arasındadır. Mizacı gereği kimseye muhtaç olmamayı, minnet etmemeyi ve inzivayı tercih ettiğinden memurlukta yükselememiş, yaşamını az bir gelirle sürdürmek mecburiyetinde kalmıştır. İlgi alanı edebiyat olmasına, döneminin önemli şairlerinden sayılmasına rağmen hiçbir devlet büyüğünü meth eden şiirler yazıp bu vesileyle yüksek rütbeli memuriyet ve daha çok gelir peşine düşmemesi bu durumunun en önemli kanıtıdır. 1575 senesinde Edirne'de vefat etmiştir. ${ }^{40}$

Divan edebiyatında beyitlerin içine çeşitli yöntemlerle isim gizleme olarak tarif edilebilecek "muammâ sanatı" ${ }^{11}$ denildiğinde akla gelen ilk isimdir. Hatta bu sanatın unutulmaya yüz tutmuşken tekrar revaç bulmasının Emrî Çelebi sayesinde olduğu söylenir.

Emrî'nin divan edebiyatında diğer bir başarısı da tarih düşürmedeki $^{42}$ ustalığıdır. Kaynaklar, onun bu husustaki maharetinin benzersiz olduğunu ve bu alanda yenilik getirdiğini kaydederler. ${ }^{43}$

"Muammâ" ve "tarih düşürme" sanatlarına olan şiddetli ilgisi matematik ilmine yakınlığını açıklayabileceğimiz tek ipucudur. Zira her iki sanat da matematiğin sayılarla yaptığını harflerle yapmaya, bir nevi problem hazırlama ve çözmeye dayanır. Bilhassa ebced hesabını iyi bilmek ve kullanmak gerekir.

Müellifin günümüze ulaşan eserleri vefatından sonra düzenlenen dîvanı ile muammâları ve bu çalışmanın konusu olan Mecmau'lGarâib fi'l-Mesâha'dır.

40 M. A. Yekta Saraç, “Emrî, Emrullah”, TDV İslâm Ansiklopedisi (DİA), 1995, c. XI, 164.

41 Bu sanatın Arap, Fars ve Türk Edebiyatlarında ortaya çıkış ve gelişimi, muammayı çözme usulleri ve bu sanatta öne çıkan müellifler ve eserleri hakkında ayrıntılı bilgi için bkz. İsmail Durmuş, "Muamma”, TDV İslâm Ansiklopedisi (DİA), 2005, XXX, 320-322; M. A. Yekta Saraç, "Muamma”, TDV İslâm Ansiklopedisi (DİA), 2005, XXX, 322-323.

42 Bir olayın tarihini mısra, beyit veya ibare içerisine ebced hesabını kullanarak gizleme anlamına gelen "tarih düşürme" hakkında kapsamlı bir çalışma için bkz. İsmail Yakıt, Türk-İslam Kültüründe Ebced Hesabı ve Tarih Düşürme, (İstanbul: Ötüken Yayınları,1992).

43Y. Saraç, "Emrî, Emrullah", 322-323. 


\section{Telif: Mecmau'l-Garâib fi'l-Mesâha}

\section{a. Tanitim}

Adı "Mesâhada bilinmeyenlerin/olağanüstü şeylerin toplandığı kitap” şeklinde çevrilebilecek, eseri keşfeden ve mevcut verilere göre en erken tarihli Türkçe müstakil mesâha kitabi ${ }^{44}$ olduğunu ortaya koyan Cevat İzgi'dir. ${ }^{45}$ Ondan sonra müellifin bu eserinden de bahseden ilk müstakil yazı İhsan Fazlığlu'nun ansiklopedi maddesidir. $^{46}$

Eserin bilinen tek nüshası Berlin'de Staatsbibliothek'te Ms. or. oct. 3014 numarada kayıtlıdır. ${ }^{47}$ Yan tarafta görülen hâtimedeki bir telif ve tesvid bir de tesvîd kaydından ve müstensih adından nüshanın müellif nüshası olmadığı anlaşılır. Buradaki bilgilere göre eserin telif ve tesvidi müellif Emrullah b. Ahmed Edirnevi eliyle 14 Safer 968'de (4 Kasım 1560) tesvidi ise Mustafa b. Hâcî Ali Edirnevi eliyle 10 Şaban 984'te (2 Kasım 1576) tamamlanmıştır. ${ }^{48}$

Dibâce sayfasına düşülen kayıtta Şeyh Süleyman Vefâî adı geçer, bir sonraki varakta bu isimle temellük kaydı bulunmasından notu bu kişinin yazdığı düşünülebilir. Nota göre eser, Dünya'nın en uzak noktalarına kadar ölçümünün kendisiyle bilindiği mesâha

44 Süleymaniye Kütüphanesi, Ayasofya koleksiyonu 2740 numarada kayıtlı Risâle-i Mesâha adlı risâle, müellifi, telif veya istinsahının tam tarihi meçhul olmasına rağmen "İlk Mesaha Risalemiz Risale-i Misâha" adıyla tanıtılmıştır. Üstelik aynı çalışmada Mecmau'l-Garâib'den şöyle bahsedilmektedir: "Osmanlı Devleti'nde, mesaha ile ilgi yazılmış ilk bağımsız Türkçe eser olarak ise Mecmau'l-Garâib fi'l-Misâha (Emrî Çelebi [yz.]: 3014) isimli eser kabul edilmektedir.” Ayrıntılı inceleme için bkz. Halime Mücella Demirhan Çavuşoğlu, "İlk Türkçe Mesâha Risâlemiz Risale-i Misâha”, Erdem 0 / 77 (Aralık 2019), 179-216.

45Cevat İzgi, Osmanlı Medreselerinde İlim, İz Yay., İstanbul 1997, c. I, 313314.

46İhsan Fazlığlu, "Emrî Çelebî", Yaşamları ve Yapıtlarılla Osmanlılar Ansiklopedisi, 1999, I, 407. Eserle ilgili materyalini benimle paylaşan İhsan Fazlıŏglu'na müteşekkirim. Müellif hakkında belki de en erken tarihli çalışmalar (bkz. "Emrî ve Dîvanı", doktora tezi, 1991, İÜ) DİA'daki maddenin de yazarı Yekta Saraç'a aittir ancak kendisi Mecmau'l-Garâib'i görmemiştir.

47 Nüshayı incelemek veya indirmek için: https://digital.staatsbibliothekberlin.de/werkansicht/?PPN=PPN807123668

48Emrullah Edirnevî, Mecmau'l-Garâib fi'l-Mesâha, (Berlin: Ms. or. oct. 3014), 55b. 


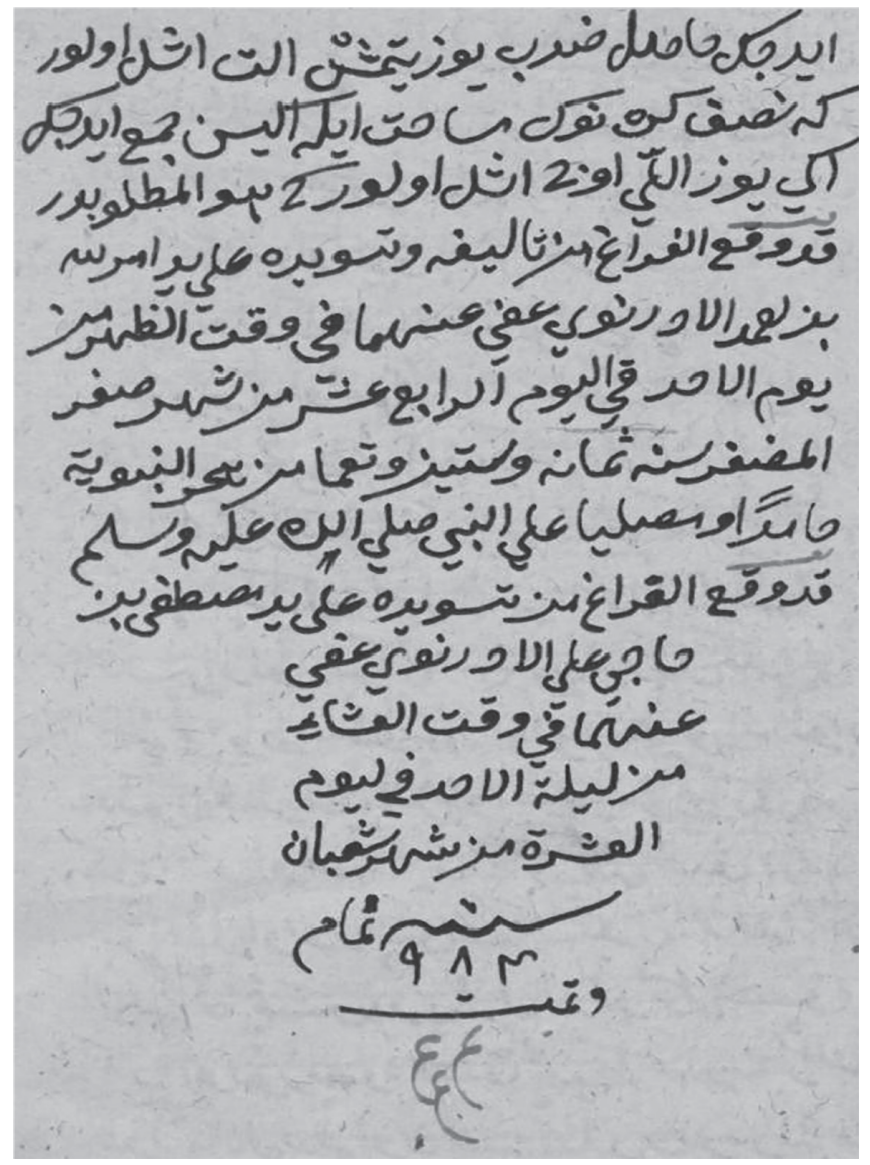

Sekil 1: Mecmau' l-Garâib' in Hâtime Sayfası

ilmi hakkında eşi benzeri olmayan bir kitaptır. Zahriye sayfasında sayfa numaralarıyla birlikte güzel bir içindekiler hazırlanmıştır. ${ }^{49}$

Müellif mukaddimeden önce önsöz kabilinden hamdele - salvele cümleleri ile eseri yazma amacını edebî bir üslupla dile getirir. Buna göre mesâha, istenen bir fen ve rağbet gören bir yöntemdir, o asırda kalem erbâbı ile rakam ashâbı yani, birçok devlet memurunun tâlib olması ve peşinden koşması gereken bir ilimdir. Dolayısıyla bukalemunun desenleri gibi tabiatın hazinesinde saklı olan bu ilmi, tabiattaki nesnelerin boyutları hakkında bilinmeyenleri Yaratandan bereketin akması gibi bu kitaba akıtmıştır. ${ }^{50}$ 


\section{b. İçerik ve matematiksel analiz}

Müellif eserini Türkçe telif etse de kullandığı tüm geometrik terimlerin Arapça asıllarını korumuştur. Yani burada terimlerin Osmanlı Türkçesiyle ifadesi gibi bir durum söz konusu olmadığından doğrudan günümüz Türkçesindeki karşılıklarıyla ifade edilmiştir. Zira söz konusu terimlerin hem Arapça hem de Türkçe karşllıklarını açıklayarak tarihi bağlam içerisindeki değişim ve dönüşümlerini vermek bu çalışmanın hedefi, sınırları ve amacına uygun bir yöntem değildir.

Mecmau'l-Garâib bir mukaddime ve beş bâbdan oluşur. Mukaddimede genel bir açıklama ve tanımlar, sırayla beş bâbda da üçgenler, dörtgenler, çokgenler, dairevi şekiller ve cisimlerin ölçümleri yer alır.

\section{Mukaddime:}

i) Mesahanın tarifi ve mesahanın aletleri olarak isimlendirdiği uzunluk birimlerinin tanımları ve birimleri dönüştürmek gerektiğinde kullanılacak temel veriler ortaya konulur. Birçok uzunluk ve alan ölçü biriminden bahseden müellif, daha kolay hesap yapabilmek için hangi birimleri hangi karşılıklarla kabul ettiğini açıklar. Buna göre " 1 eşel=10 nişan", " 1 nişan=10 şibr", " 1 şibr=10 1sba", "1 1sba $=10$ şeîr"'dir..$^{51}$

ii) Hendesi terimlerin açıklamalarına yer verilir. Bu temel terimleri birincil ve ikincil olanlar şeklinde tasnif edebiliriz:

Birincil terimler: Nokta, çizgi, yüzey ve cisimdir. ${ }^{52}$

Müellif, "Kâbil-i işaret-i hissî olan her nesne, eğer hiçbir yönden bölünme kabul etmezse buna nokta derler" cümlesiyle konuya başlar. Burada tanımda kullanılan iki unsur dikkati çeker: "hissi/ duyusal işaret edilebilirlik" ve "bölünemezlik". Yani, vehmi olmayıp tek başına, ayrık olarak var olması sayesinde duyusal işarete konu olanların bölünme kabul etmeyenleri noktadır. Bu durumda "bölünemezlik" unsuru Öklid'in Elemanlar'da noktayı "parçası olmayan şeydir" şeklinde tanımlamasına paraleldir. Ancak müellif buna, İslam ve Osmanlı hendese ve mesâha literatürlerinde sıkça rastlanacağı üzere "hissi işaret" şartını da eklemiştir. Bu tavrıyla sürekli niceliklerin maddeden soyut vehmî varlıklar olarak anlaşıl- 
masının önüne geçmek istemiş olabilir. Böylece başta nokta olmak üzere sürekli niceliklerin tamamının "vehmi varlıklar" olduğu iddiasına karşı konumunu belirler. Bu konumu da "el-cüz la yetecezzâ/ parçalanmayan parça” kavramıyla özdeşleşen kelâmî yaklaşımı çağrıştırır. Çizgi, yüzey ve cisim de bu tanıma uygun şekilde sırayla bir, iki ve üç yönden bölünme kabul edenlerdir. Çünkü çizgi noktalardan, yüzey çizgilerden, cisim de yüzeylerden meydana gelir.

İkincil terimler: Doğru, eğri, düzlemsel yüzey, kenar, düzlemsel açı, dik açı, yükseklik, taban, geniş açı, dar açı, paralel çizgiler ve düzlemsel şekildir..$^{53}$

Asli terimlerin durumlarının incelenmesiyle bu ikincil terimler meydana gelir. Örneğin çizgi düz ise doğru ki aksi takdirde eğri olurdu ve iki doğrunun kesişmesiyle açı, bunun büyüklüğünün değişmesiyle de açı türleri oluşur.

Üçgen türleri: Eşkenar üçgen, ikizkenar üçgen, dar açılı ikizkenar ve geniş açllı ikizkenar üçgen, çeşitkenar üçgen. ${ }^{54}$
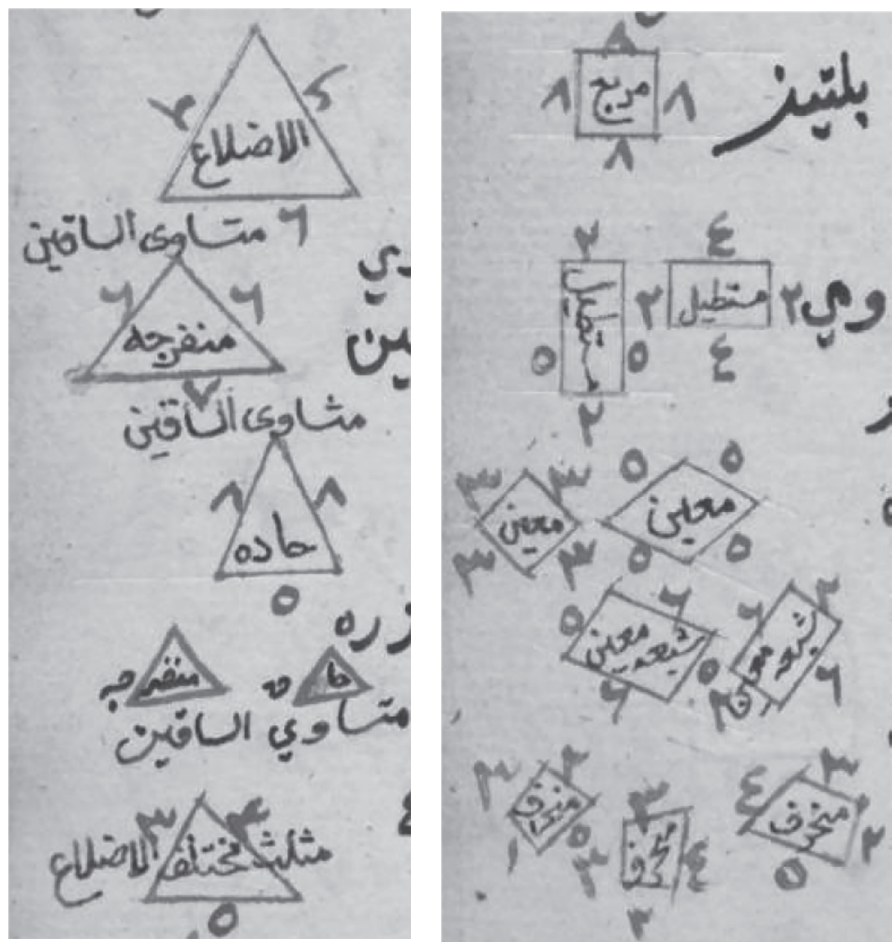

Dîvân

Sekil 2: Mecmau' 'I-Garâib’deki Üçen ve Dörtgen Ceșitleri

53A.g.e., vr. 5a-5b.

54A.g.e., vr. 6a. 
Dörtgen türleri: Kare, dikdörtgen, eşkenar dörtgen, deltoit, paralelkenar, yamuk. ${ }^{55}$

Dört kenarı hem eşit hem de dik açılı olursa kare, açılar dik ama karşılıklı iki kenarlar eşit olursa dikdörtgen, kenarlar eşit ama açılar dik olmazsa eşkenar dörtgen, karşılıklı kenarlar eşit ama açılar dik olmazsa paralelkenar, iki şart da olmazsa yamuk olur. Bu şekildeki bir anlatım ile dörtgenlerin meydana gelişini anlamak ve birbirlerinden farklarını ayırt etmek oldukça kolaylaşır, öğrenim faaliyetini hızlandırır.

Çokgenler: Beşgen, altıgen, yedigen, sekizgen, dokuzgen, ongen ... ${ }^{56}$
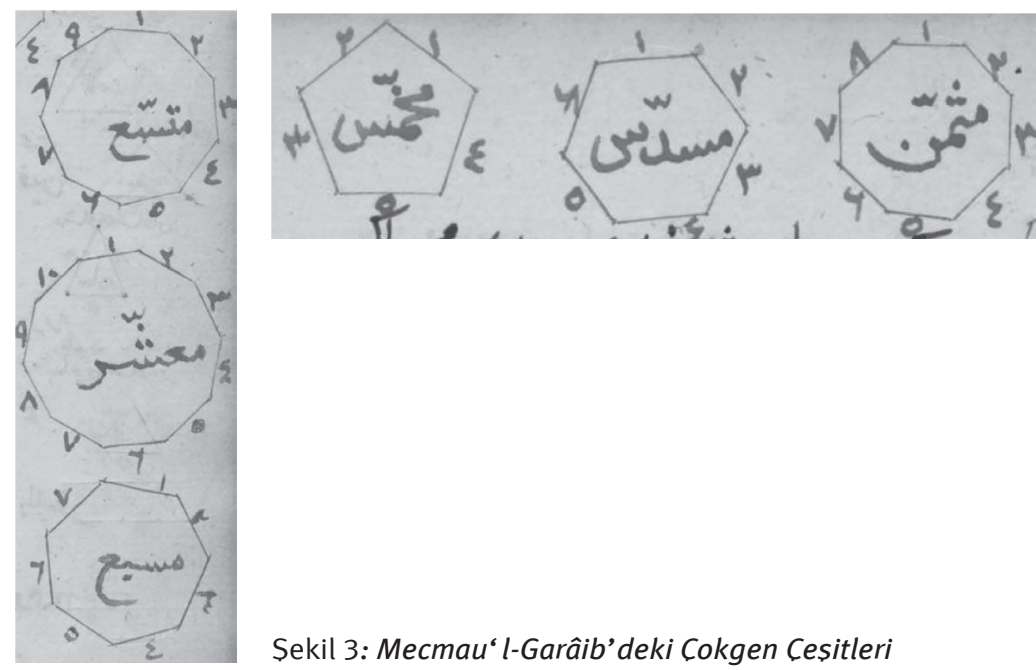

Sekil 3: Mecmau' 'l-Garâib’deki Cokgen Ceșitleri

Daire ile ilgili terimler: Merkez, çevre, çap, yarıçap, kiriş, yay parçası, ihlîlicî veya beyzî şekli. ${ }^{57}$ Eğer yarım daire yayından daha

55A.g.e., vr. 6a.

56A.g.e., vr. $6 b$.

57 Son iki şekil olan ihlîlicî ve beyzî terimlerinin modern matematikte tam karşılığı bulunmadığı için aynen kullanılmıştır. Birbirine eşit iki yarım daire yayından küçük yayın ters yönden ve yayların uç noktalarından birleştirilmesiyle meydana gelir. Metinde ihlîlicî ve beyzî eş anlamlı olarak kullanılırken nüshadaki çizimde ihlîlicîyi oluşturan yaylar yarım daire yayına daha yakınken beyzîyi oluşturan yaylar yarım daire yayına daha uzaktır. Mecmau'l-Garâib'den yaklaşık bir asır önce telif edilen ve Fatih Sultan Mehmed'e sunulan el-îkna adlı mesaha eserinde de bu iki terimin eş anlamlı kullanıldığı görülür ancak daha erken dönem eserlere dönüldüğünde söz konusu şekil için çoğunlukla sadece ihlîlicî terimiyle karşılaşılır. Son 
küçük iki eşit yay parçası ters yönde uç noktalarından birleşirse ihlîlicî veya beyzî şekli meydana gelir. ${ }^{58}$
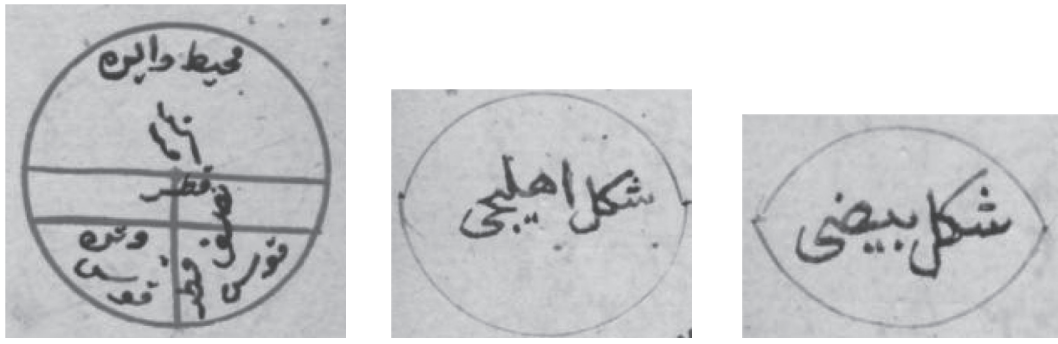

Sekil 4: Mecmau'l-Garâib’deki Dairevi Sekiller

Cisimler: Küre, dik silindir, dik koni. ${ }^{59}$
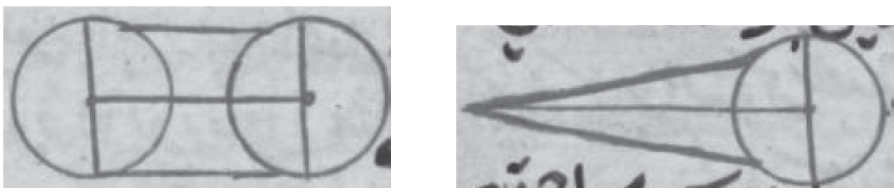

Sekil 5: Mecmau“ l-Garâib’deki Dik, Dairesel Silindir ve Koni

\section{Birinci Bâb: Üçgenlerin alanı.}

Üç çeşit üçgenin alanlarını hesaplama ile ilgili durumlar üç fasılda incelenir.

i)Eşkenar üçgenin alanı: Yüksekliği bulma yöntemleri, eşkenar üçgen alanını 3 farklı yöntemle hesap etme, yükseklik bilgisi ile kenar mikdarını belirleme, alanın değeri ile kenar değerini bulma ve alanın değerinden yükseklik değerini bulma olmak üzere beş konu ile izah edilir. ${ }^{60}$

olarak, buradaki beyzî terimiyle modern Farsçada kullanılan ve elips şekline karşılık gelen beyzî terimi karıştırılmamalıdır. 


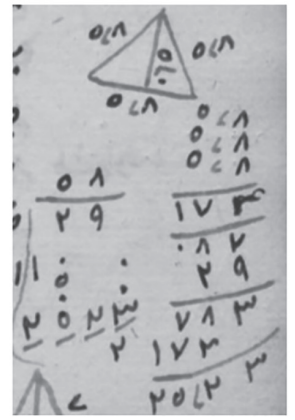

Örnek: Kenarları 5 eşel ve 8 nişan olan bir eşkenar üçgenin yüksekliği nedir?

Çözüm: $h=$ yükseklik,,$C=$ çevre, $a=$ kenar ve $e=e s ̧ e l, n=$ nişan, ş = şibr olmak üzere

$$
\begin{aligned}
h=\sqrt{\frac{C^{\frac{C}{2}} \times \frac{a}{2}}{}} & \text { dır. Bu durumda } h=\sqrt{\frac{3 \times(5 e+8 n)}{2} \times \frac{(5 e+8 n)}{2}} \\
& =\sqrt{\frac{17 e+4 n}{2} \times(2 e+9 n)} \\
& =\sqrt{(8 e+7 n) \times(2 e+9 n)}=\sqrt{25 e+2 n+3 \varsigma} \\
& =5 \text { eşeldir. }
\end{aligned}
$$

Sekil 6: Mecmau'l-Garâib’deki Eșkenar Ücgenlerde Yükseklik Hesaplama Örneği ile Bunun Modern Matematikteki Gösterimi ${ }^{61}$

ii)İkizkenar üçgenin alanı: Yüksekliği bulma, ikizkenar üçgenin alanını hesaplama, tabanın değerini hesaplama, ikiz kenarları hesaplama şeklinde dört konu yer alır. ${ }^{62}$

iii)Çeşitkenar üçgenin alanı: Yüksekliğin indiği kenarın (taban) iki farklı parçasını bulma (taban parçalarını bulma), taban parçalarından yüksekliği bulma, çeşitkenar üçgenin alanını bulma, alandan yüksekliği ve taban parçalarını bulma, taban ve yükseklikten kenarları bulma hakkında beş ayrı konuda ortaya konulur. ${ }^{63}$
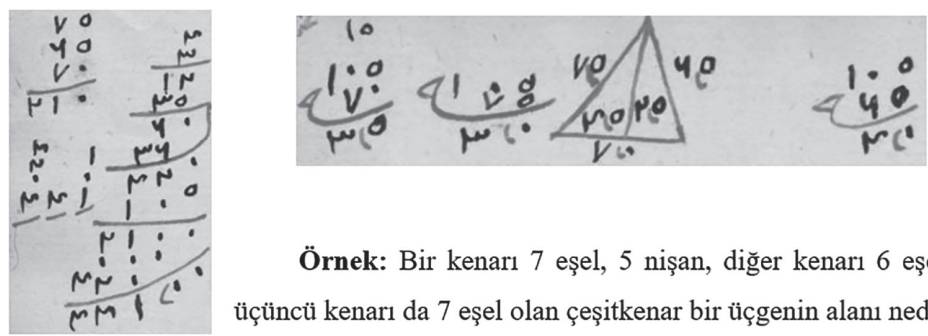

Örnek: Bir kenarı 7 eşel, 5 nişan, diğer kenarı 6 eşel, 5 nişan ve

61 Makale hacminin sınırları gereği bu ve bundan sonraki örneklerin eserdeki matematiksel işlem gösterimleri ve bunların modern matematiğe çevirileri sunulmuştur. $\mathrm{Bu}$ işlemlerin ayrıntılı açıklamaları için dipnotlarda verilen varak numaralarına bakılabilir. Eserin çevrimiçi okunabileceği veya indirilebileceği bağlantı 48 numaralı dipnotta verilmiştir.

62A.g.e., vr. 9a-10b.

63A.g.e., vr. 10b-18a. 
Çözüm: $e=e s ̧ e l, n=$ nişan, $C$ $=$ çevre,$Y C ̧=$ yarımçevre, $A=$ alan, $a, b, c$ kenarlar

$$
\begin{gathered}
Y C ̧=\frac{a+b+c}{2} \text { ve } A=\sqrt{Y C ̧ \cdot[(Y C ̧-a) \cdot(Y C ̧-b) \cdot(Y C ̧-c)]} \Rightarrow \\
Y C ̧=\frac{7 e+5 n+6 e+5 n+7 e}{2}=10 e+5 n \\
A=\sqrt{(10 e+5 n) \cdot[(10 e+5 n-(7 e+5 n)) \cdot(10 e+5 n-(6 e+5 n)) \cdot(10 e+5 n-7 e)]} \\
=\sqrt{(10 e+5 n) \cdot(3 e+5 n) \cdot 12 e}=\sqrt{441 e}=21 e
\end{gathered}
$$

Sekil 7: Mecmau' 'l-Garâib’deki Ceșitkenar Ücgen Alan Hesaplama Örneği ile Bunun Modern Matematikteki Gösterimi

\section{İkinci Bâb: Dörtgenlerin alanı}

Beş çeşit dörtgen ve alanlarını hesaplama yöntemleri üç fasılda işlenir.

i) Kare ve dikdörtgenin alanı: Bir kenar veya köşegenden alanın çıkarılması, köşegeni bulma yöntemi, köşegenden kenarı bulma yöntemi olmak üzere üç konu kare için, dikdörtgen alanını bulma yöntemi, köşegeni bulma yöntemi, uzun kenar ile kısa kenarı bulma yöntemi, köşegen ile kısa ve uzun kenar arasındaki farktan alanı bulma yöntemi, alan ile kısa ve uzun kenar arasındaki farktan

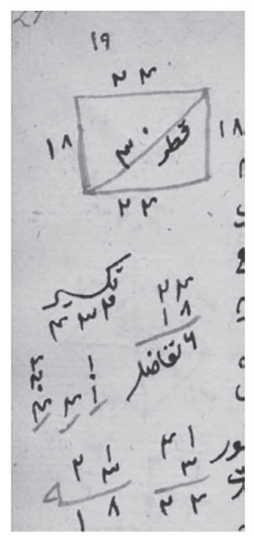

Örnek: Dikdörtgenin alanı 432 eșel, uzun ile kısa kenarları arasındaki fark 6 eşeldir. Uzun ve kısa kenar kaç eşeldir?

Çözüm: Uzun kenar $=a, \quad$ kısa kenar $=b$

$$
\begin{gathered}
a, b=\sqrt{\left(\frac{a-b}{2}\right)^{2}+A \pm\left(\frac{a-b}{2}\right)^{\prime} \text { dir. Bu durumda } a, b} \\
=\sqrt{\left(\frac{6}{2}\right)^{2}+432 \pm \frac{6}{2}=\sqrt{441} \pm 3=21 \pm 3 \Rightarrow a} \\
=24 \text { eşel ve } b=18 \text { essel. }
\end{gathered}
$$

Sekil 8: Mecmau'l-Garâib’deki Dikdörtgenin Alanından Kenar Hesaplama Örneḡi ile Bunun Modern Matematikteki Gösterimi 
kısa ve uzun kenarı bulma yöntemi şeklinde beş konu da dikdörtgen için anlatılır. ${ }^{64}$

ii) Eşkenar dörtgen, Deltoit ve Paralelkenarın alanı: Alanı bulma yöntemi, iki köşegenden kenarı bulma yöntemi, kenarlar ve bir köşegenden diğer köşegeni bulma yöntemi, kenar ve alandan iki köşegeni bulma yöntemi olmak üzere dört metotla eşkenar dörtgen, alanı bulma yöntemi, köşegeni bulma yöntemi diye iki konu ile deltoit ve bir başlıkla da paralelkenar öğretilir. ${ }^{65}$

iii) Yamuğun alanı: Yamuk ile ilgili işlemler üç ana başlık altında incelenir. (a) Dik yamuk; alanını bulma, yüksekliğin böldüğü taban parçasını, yüksekliği ve kenarı bulma yöntemleri şeklindedir. (b) İkizkenar yamuk; alanını bulma ve yüksekliği bulma işlemleri verilir. İkizkenar yamuk başlığı altında ayrıca iki farklı yamuk türü ilgili işlemlere yer verilir. Bunlar; iki kenarı paralel, diğer iki kenarı farklı olup yüksekliği şeklin içinde veya dışında bulunan yamuklardır. Bunların alanını bulma, harici veya dahili yüksekliğini bulma, harici yükseklikten oluşan üçgenin kenarını bulma işlemleri açıklanır.

(c) Çeşitkenar ve paralel olmayan yamuğun alanını bulma işlemi. ${ }^{66}$
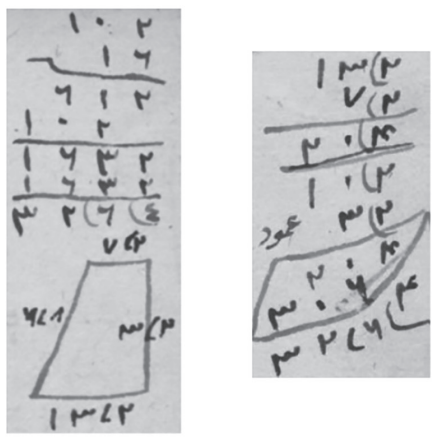

Örnek: Paralel kenarlarından uzun olanı 13 eşel, 2 nişan kısa olanı 7 eşel, 2 nişan, dik kenarı 3 eşel, 2 nişan ve yamuk kenarı da 6 eşel, 8 nişan olan bir dik yamuğun alanı nedir?

Çözüm:

Paralel uzun kenar $=a, \quad$ Paralel klsa kenar $=b$, Dik kenar $=c$ ve Yamuk kenar

$$
\begin{aligned}
& =d, e=e \text { şel, } n=\text { nişan, ş = şibr ve } A=\text { alan ve } A=\left(\frac{a+b}{2}\right) \cdot c \Rightarrow A \\
& =\left(\frac{13 e+2 n+7 e+2 n}{2}\right) \cdot(3 e+2 n)=\frac{20 e+4 n}{2} \cdot(3 e+2 n) \\
& =(10 e+2 n) \cdot(3 e+2 n)=32 e+6 n+4 \text { ş } \Rightarrow 32 \text { eşel, } 6 \text { nişan, } 4 \text { şibr' dir. }
\end{aligned}
$$
Modern Matematikteki Gösterimi 


\section{Üçüncü Bâb: Çokgenlerin alanı}

Beş, altı yedi, sekiz ve ongen ile düzgün olmayan çokgenin alanı olmak üzere altı fasıldır.

i) Düzgün beşgenin alanı: Küçük çap (beşgenin içine çizilen ve kenarlarına temas eden dairenin çapı) ve kenardan büyük çapı bulma, büyük çap (beşgenin dışına çizilen ve köşelerine temas eden dairenin çapı) ve kenardan küçük çapı bulma, küçük ve büyük çaptan kenarı bulma, küicük çap ve kenardan alanı bulma, alan ve kenardan küçük çapı bulma, alan ve küçük çaptan kenarı bulma, alan ve küçük çaptan kenarlar toplamını bulma olmak üzere yedi konu bulunur. ${ }^{67}$

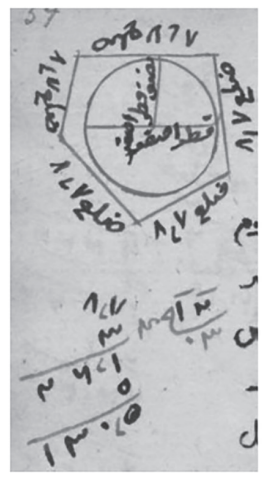

Örnek: Bir düzgün beşgenin küçük çapı 12 eşel, bir kenarı 8 eșel ve 7 nişandır. Beşgenin alanı kaçtır?

Çözüm: Çap $=R$, kenar $=$ a ve $A=\left(\frac{R}{4} \times a\right) \times 5 \Rightarrow$

$$
\begin{array}{r}
A=\frac{12}{4} \times(8 e+7 n) \times 5=(26 e+5 n) \times 5 \\
=130 \text { eşel ve } 5 \text { nişandır. }
\end{array}
$$

Sekil 10: Mecmau' '-Garâib’deki Besgen Alanı Hesaplama Örneḡi ile Bunun Modern Matematikteki Gösterimi

ii) Düzgün altıgenin alanı: Altıgenin alanını bulma, kenardan küçük çapı, alan ve kenardan da büyük çapı bulma, küçük çaptan kenarı bulma, kenardan büyük çapı bulma şeklinde dört konudan meydana gelir. ${ }^{68}$

iii) Düzgün yedigenin alanı: Büyük çaptan kenarı bulma, kenardan büyük çapı bulma, kenar ve büyük çaptan küçük çapı bulma, küçük çap ve kenardan alanı bulma diye dört konudan müteşekkildir. ${ }^{69}$ 
iv) Düzgün sekizgenin alanı: Sekizgenin alanını bulma, kenardan, küçük çapı bulma, küçük çaptan, kenarı bulma, kenardan, büyük çapı bulma şeklinde dört konudan oluşur. ${ }^{70}$

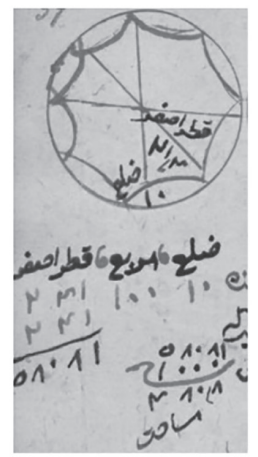

Örnek: Bir kenarı 10 eşel olan düzgün sekizgenin alanı kaçtır?

Çözüm: $\quad a=$ kenar $, e=e s ̧ e l, n=n i s ̧ a n, K C ̧=k$ üçü $k$ çap, $A=$ alan ve $K C ̧=\sqrt{2 a^{2}}+a$ ve $A=K C^{2}-a^{2} \Rightarrow A=\left(\sqrt{2 a^{2}}+a\right)^{2}$ $a^{2}$ ve $A=\left(\sqrt{2 \cdot(10 e)^{2}}+10 e\right)^{2}-(10 e)^{2}=(24 e+1 n)^{2}-$ $100 e=580 e+8 n-100 e=480 e+8 n \Rightarrow$ 480 eşel, 8 nişan'dır.

Sekil 11: Mecmau' 'l-Garâib’deki Sekizgen Alan Hesabı Örneği ile Bunun Modern Matematikteki Gösterimi

v) Düzgün ongenin alanı: Ongenin alanını bulma, kenardan, küçük çapı bulma, kenardan, büyük çapı bulma diye üç konudan oluşur. ${ }^{71}$

vi) Düzgün olmayan çokgenlerin alanı: Farklı boyuttaki doğru parçalarıyla elde edilmek şartıyla beşgen üç üçgene, altıgen dört üçgene, yedigen beş üçgene... bölünerek üçgen bahsinde anlatıldığı gibi hesaplanır. ${ }^{72}$

Dördüncü Bâb: Daire, daire parçası, oval, selcî/dik oval ve elips şeklinin alanı

Daire, daire dilimi, daire parçasından oluşan şekiller ve çeşitli problemler olmak üzere dört fasıldan müteşekkildir.

i) Dairenin alanı: Çaptan dairenin çevresini bulma, çevreden çapı bulma, alandan çapı bulma, daire alanını bulmanın diğer yolları (7 farklı yol) diye dört konu yer alır. ${ }^{73}$

ii) Daire diliminin alanı: Yarıçap ile daire diliminin yayının yarısının çarpımından elde edilir. ${ }^{74}$

Dîvân

$2021 / 2$

\footnotetext{
70A.g.e., vr. 38b-40b.

71 A.g.e., vr. 40b-42a.

72A.g.e., vr. 42a-42b.

73A.g.e., vr. $42 b-45 b$.

74 A.g.e., vr. $45 b-46 a$.
} 
iii) Daire parçasının alanı: Oval/yumurtamsı (ihlîlîcî) şeklin alanı, dik oval (selcî) şeklin alanı, elips şekli ve halkanın alanı olmak üzere üç konu mevcuttur. ${ }^{75}$

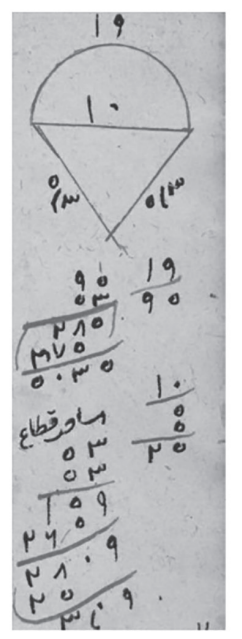

Örnek: Yayı 19 eşel, tabanı 10 eșel olan daire parçasının merkeze uzaklığ 5 eşel ve 3 nişandır. Daire parçasının alanı kaçtır?

Çözüm: $\quad$ Yay $=a$, taban $=b$, yarlçap $=r$ ve $A=\frac{a}{2} \times r-$

$\sqrt{\left(r^{2}-\left(\frac{b}{2}\right)^{2}\right)} \times \frac{b}{2} \Rightarrow A=\frac{19 e}{2} \times(5 e+3 n)-$

$\sqrt{\left((5 e+3 n)^{2}-\left(\frac{10 e}{2}\right)^{2}\right)} \times \frac{10 e}{2}=(9 \mathrm{e}+5 \mathrm{n}) \times(5 e+3 n)-$

$\sqrt{(28 e+9 n-25 e)} \times 5 e=50 e+3 n-(1 e+7 n) \times 5 e=50 e+$

$3 n+5 s ̧-(8 e+5 n)=41 e+8 n+5 s ̧ \Rightarrow$ oval şeklin alanı $A=$

$2 \times(41 e+8 n+5 s ̧)=8 e+7 n$ olur .

Sekil 12: Mecmau' 'L-Garâib’deki Daire Parçası Alan Hesabı Örneḡi ile Bunun Modern Matematikteki Gösterimi

iv) Çeşitli problemler: Dik üçgenin içindeki karenin kenarını bulma, eşkenar üçgenin içindeki karenin kenarını bulma, ikizkenar üçgenin içindeki karenin kenarını bulma, eşkenar üçgenin içindeki dairenin çapını bulma, daireyi çevreleyen eşkenar üçgenin kenarını bulma, dairenin içindeki eşkenar üçgenin kenarını bulma, eşkenar üçgeni çevreleyen dairenin çapını bulma, dairenin içindeki karenin kenarını bulma, daireyi çevreleyen karenin kenarını bulma olmak üzere dokuz başlıkta izah edilir. ${ }^{76}$

\section{Beşinci Bâb: Küre ve silindirin yüzey alanı}

Küre, silindir ve koninin yüzey alanlarının ölçümü olmak üzere üç fasıldır.

i) Kürenin yüzey alanı ile çapı ve en büyük daireyi bulma: Kürenin çapı ile en büyük dairesini bulma, kürenin yüzey alanı, kürenin yüzey alanından çapı bulma olmak üzere üç konuda izah edilir. ${ }^{77}$ 
ii) Silindirin yüzey alanı: Çap, daire çevresi ve alanını bulma ile silindir yüzey alanını bulma şeklinde iki konudan müteşekkildir. ${ }^{78}$

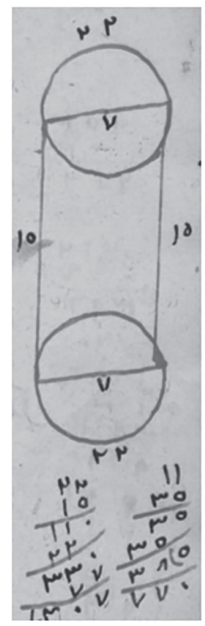

Örnek: Çapı 7 eşel, yüksekliği 15 eşel olan bir dik dairesel silindirin yüzey alanı kaçtır?

Çözüm: Çap $=R, Y$ ükseklik $=h, \pi=\frac{22}{7}$ ve

$$
\begin{aligned}
& A=2 \times \pi \times\left(\frac{R}{2}\right)^{2}+2 \times \pi \times \frac{R}{2} \times h \Rightarrow \\
& A=2 \times \frac{22}{7} \times\left(\frac{7 e}{2}\right)^{2}+2 \times \frac{22}{7} \times \frac{7 e}{2} \times 15 e \\
&= 2 \times 11 \times(3 e+5 n)+22 \times 15 e \\
&=2 \times(38 e+5 n)+330 e=77 e+330 e=407 e
\end{aligned}
$$

Sekil 13: Mecmau' l-Garâib’deki Dik Dairesel Silindirin Yüzey Alanı Hesabı Örneği ile Bunun Modern Matematikteki Gösterimi

iii) Koninin yüzey alanı: Taban, daire çevresi ve çapı bulma ile koninin yüzey alanını bulma olmak üzere iki konudan oluşur. ${ }^{79}$

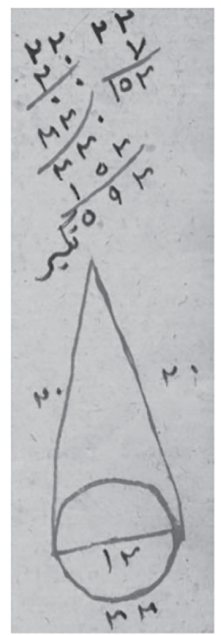

Örnek: Taban çapı 14 eşel, yanal yüksekliği (ana doğrusu) 20 eşel olan bir koninin yüzey alanı nedir?

Çözüm: $e=$ eșel, $R=$ çap, $\pi=\frac{22}{7}, Y Y=$ yanal yükseklik, $C=$ çevre, $D A=$ daire alanı, $K A=$ koni alanı ve

$$
\begin{aligned}
K A=\frac{C}{2} \cdot Y Y & +D A \Rightarrow K A=\frac{14 \frac{22}{7}}{2} \cdot 20+\left(\frac{14}{2}\right)^{2} \cdot \frac{22}{7}=22 \cdot 20+7 \cdot 22 \\
= & 440+154=594 \text { eşel. }
\end{aligned}
$$

Sekil 14: Mecmau'l-Garâib’deki Dik Dairesel Koninin Yüzey Alanı Hesabı Örneḡi ile Bunun Modern Matematikteki Gösterimi

78A.g.e., vr. 53a-54b.

79A.g.e., vr. 54b-55b. 


\section{Değerlendirme}

Yukarıdaki tanıtım ve incelemeler neticesinde Mecmau'l-Garâib şöyle değerlendirilebilir:

a) Eserin ilk müstakil Türkçe mesâha kitabı olmasından başlamak gerekirse, klasik Arapça matematik terimlerinin tamamının herhangi bir çeviriye uğramaksızın aynen kullanıldığı, bu terimlerin fiil versiyonlarının da "naks eylemek", "cem etmek”, “darb eylemek”, “cezr almak”, "murabba etmek” ve "mümâs olmak” gibi Türkçe yardımcı fiiller marifetiyle ifade edildiği görülür. Bu durum, telif tarihi bilinen en erken Türkçe mesâha kitabı için olağan olarak nitelenebilir. Daha sonraki Türkçe teliflerde bu durumun nasıl devam ettiğinin araştırılması ise başka çalışmaların konusudur.

b) Mukaddimede dönemin yaygın kullanılan uzunluk ve alan ölçü birimleri hakkında bilgi verilir. Burada önce "diyar-1 Arab" da yaygın olan birimler ve birbirlerine dönüşümlerinden sonra "vilâyât-1 Rum”da kullanılan ölçü birimlerinden yine birimler arasındaki ilişkilerle birlikte bahsedilir. En son da hesap alanında kabul edilip kullanılan birimler ve karşılıkları verilir. Bu durumda müellifin yaşadığı bölgede kullanılan ölçülerle kitaptakilerin farklı olmasından eserin pedagojik bir niyetle üretildiği düşünülebilir. Bununla birlikte sadece bu ipucuna dayanarak eserin ders kitabı olarak kullanıldığı kesin bir biçimde söylenemez. Fakat her halükârda eserden Osmanlı'nın farklı bölgelerinde 16. asırda yaygın olan ölçü birimleri hakkında ayrıntılı bilgi edinilebilir.

c) Eser boyunca tüm örneklerdeki sayısal değerlerin tamamının ölçü birimleriyle verilmesi, bir taraftan risâleyi mesâha geleneğindeki nadir örneklerden biri haline getirir diğer taraftan da 16. asırda mesâhada uygulamaya yönelim veya ihtiyacın seviyesini gösterir. Zira mesahanın tarihsel sürecinde tanıtılan eserlerde de görüldüğü gibi sayısal hesaplama işlemlerinde "zirâ" dışındaki ölçü birimlerini de kullanma durumu yaygın değildir.

d) Telifteki her bir iki ve üç boyutlu şeklin alan veya uzunluk hesaplamalarında mümkün olan tüm ihtimaller düşünülmüş, verilenler ve istenenlerin farklı kombinasyonlarıyla oluşan tüm durumlar için açıklama yapılmış, çoğu için de örnekler verilmiştir. Bu durum eserin oldukça kapsamlı bir biçimde hazırlandığını gösterir.

e) Çokgenlerin üzerinde ayrıntılı bir şekilde durulması, beşgen, altıgen, yedigen, sekizgen ve ongenin ayrı fasıllarda incelenmesi, bu şekilleri daha çok zanaatkârların kullandıkları düşünülürse ese- 
rin hedef kitlesi içerisine bu meslek grubu da dahil edilebilir. Dairevi şekiller hakkındaki dördüncü bâbın son konusu olan "çeşitli problemler"de verilen örneklerin Büzcani'nin zanaatkârlar için hazırladığı mesâha kitabındaki iç içe geçmiş şekiller ile benzerlik göstermesi de bunu destekler.

f) Küre, silindir ve koni cisimlerine tahsis edilen son bâb önceki bâblara nispetle özet şekilde hazırlanmıştır ve bu yüzden sadece üç varaktan oluşur. Burada dikkati çeken husus bu cisimler ve ilave olarak kozalak cisminin hacim hesaplamalarına yer verilmeyip yüzey alanlarının ölçümleriyle yetinilmesidir. Esasında mesâha geleneğinde hacim hesaplamaları çoğunlukla yüzey alanı ölçümlerine dayanır, yani doğrudan bir hacim formülü uygulamak yerine yüzey alan ölçüm sonucunun kullanıldığı hacim ölçüm yöntemleri yaygındır. Dolayısıyla mesâha metinlerinin büyük kısmında cisimlerin yüzey alanları anlatıldıktan sonra bu ölçümlere dayanan hacim ölçümleri de kısaca ortaya konulur. Mecmau'l-Garâib'de hacim hesaplarına yer verilmemesinin birkaç sebebi olabilir: i) yüzey alanını bildikten sonra hacmi hesaplamak kolaylaştığından zaten bilineceği varsayılmış olabilir, ii) eserden faydalanacak kitlenin hacim hesabına ihtiyaç duymayacağı düşünülmüş olabilir, iii) müellif eserinin bilhassa bir ve iki boyutlu ölçümlerle sınırlandırmak istemiş olabilir.

g) Eser boyunca matematiksel işlemlerde, ölçü birimleri kullanmanın zorluğuna rağmen hata bulunmaması, müellifin dikkatine ve dakikliğine bağlanabilir. Buna ilave olarak kullanılan formül ve yöntemlerin büyük bölümünün günümüzde de geçerli olduğu ve matematik eğitiminin çeşitli kademelerinde kullanıldığı söylenebilir.

h) Son olarak, mevcut araştırmalara göre eserin tek nüshasının bulunması, çok fazla yaygınlaşmadığına, en azından ders kitabı olarak kullanılmadığına işaret sayılabilir. Bununla birlikte hem müellifin hem de müstensihin nisbelerinin Edirnevi olması, ayrıca müellifin yaşamını Edirne'de geçirmesi dolayısıyla eserin, Trakya bölgesinde arazi ölçümü yapan memurlar ve zanaatkârlar gibi belirli iş grupları tarafından kullanılıp yerel olarak kaldığı tahmin edilebilir. Bu durumda eserin bilinen en erken tarihli Türkçe mesaha kitabı olmasının etkisi de hesaba katılmalıdır. Bunun dışında eserin hacmi, kullandığı dil ve üslup, verdiği ayrıntı ve konularının çeşitliliğine göre seviyesi “orta” olarak ifade edilebilir. 


\section{KAYNAKÇA}

Aksan, Virginia, "What's Up in Ottoman Studies?”,Journal of the Ottoman and Turkish Studies Association 1/1-2 (2014), 3-21.

Arıcı, Müstakim (ed.), İlimleri Sınıflamak: İslam Düşüncesinde İlim Tasnifleri, İstanbul: Klasik Yayınları, 2020.

Armağan, Mustafa vd., Osmanlı Tarihini Yeniden Yazmak Gerileme Paradigmasının Sonu, İstanbul: Timaş Yayınları, 2014.

Baga, Elif, Osmanlı Klasik Dönemde Cebir, İstanbul: Marmara Üniversitesi, Doktora Tezi, 2012.

Baga, Elif, "İslâm Matematik Tarihinde Hisâbî Cebir Geleneği ve IX./XV. Asırdaki Zirvesi: İbnü'l-Hâim'in el-Mümti“ Adlı Eseri”, Nazariyat 3/2 (Nisan 2017), 69-126.

Bağdadi, Abdülkâhir, Kitâb fi'l-misâha. İstanbul: Süleymaniye Kütüphanesi, Laleli, 2708/2, vr. 99b-117a.

Büzcânî, Ebu'l-Vefâ, Kitâb fìmâ yehtâcü ileyhi's-sâni' min a'mâli'l-hendese, İstanbul: Süleymaniye Kütüphanesi, Ayasofya, 2753.

Durmuş, İsmail, “Muamma”, TDV İslâm Ansiklopedisi, XXX, 320-322.

Edirnevî, Emrullah: Mecmau'l-Garâib fi'l-Mesâha, Staatsbibliothek zu Berlin, Orientabteilung, Ms. or. oct. 3014.

Fazlıŏlu, İhsan, "Emrî Çelebî”, Yaşamları ve Yapıtlarıyla Osmanlılar Ansiklopedisi, I, 407.

Fazlığlu, İhsan, Uygulamalı Geometrinin Tarihine Giriș: el-İknâ' fì İlmi’lMisâha, İstanbul: Dergah Yayınları, 2004.

Fazlığlu, İhsan, "Mesâha”, TDV İslâm Ansiklopedisi, XXIX (2004), 261-264.

Fazlığlu, İhsan, “Hendese”, TDV İslâm Ansiklopedisi, XVII (1998), 199-208.

Fazlığlu, İhsan, “Devlet'in Hesabını Tutmak: Osmanlı Muhasebe Matematiğinin Teknik İçeriği Üzerine”, Kutadgubilig Felsefe-Bilim Araştırmala$r l 17$ (2010), 165-178.

Genç, Mehmet, Osmanlı İmparatorluğunda Devlet ve Ekonomi, İstanbul: Ötüken Yayınları, 2013.

Harizmi, Mefâtihu'l-Ulûm, thk. İbrahim Ebyari, Beyrut, 1989.

Haddad, Makram ve Aziz Doğanay, "Kitâb fîmâ Yehtâcü İleyhi’s-Sâni" min A'mâli'l-Hendese Adlı Eserin Âidiyet Meselesi Üzerine”, Türk-İslam Medeniyeti Akademik Araştırmalar Dergisi 12/23 (Kış 2017), 139-152.

İhsanoğlu, Ekmeleddin vd., Osmanlı Matematik Literatürü Tarihi, I-II, IRCICA, İstanbul 1999.

İzgi, Cevat, Osmanlı Medreselerinde İlim, İstanbul: İz Yayınları, 1997. 
İzgi, Cevat, "Nûman Efendi, Eğinli”, TDV İslâm Ansiklopedisi, XXXIII (2007), 235-236.

Mühtedî, Osman b. Abdülmennân: Hediyyetü'l-Mühtedî, Kahire: Dâru'lKutub, Riyâza, 695.

Necipoğlu, Gülru, The Topkapi Scroll: Geometry and Ornament in Islamic Architecture, USA: The Getty Center Publications, 1995.

Nîsâbûrî, Nizâmeddin, Hesap Biliminde Kllavuz, Haz. Elif Baga, İstanbul: Yazma Eserler Kurumu Yay., 2020.

Özvar, Erol, “Osmanlı Tarihini Dönemlendirme Meselesi ve Osmanlı Nasihat Literatürü”, Divan: Disiplinlerarası Çalışmalar Dergisi (Aralık 1999), 135-151.

Râşid, Rüşdî, Rlyâdiyyâtu'l-Harizmi: Te'sîs ilmi'l-Cebr, çev. Nikola Haris, Beyrut 2010.

Saraç, M. A. Yekta, “Emrî, Emrullah”, TDV İslâm Ansiklopedisi, XI, 164.

Saraç, M. A. Yekta, "Muamma”, TDV İslâm Ansiklopedisi, XXX, 322-323.

Shefer-Mossensohn, Miri, Osmanlı'da Bilim Kültürel Yaratı ve Bilgi Alışverişi, İstanbul: Türkiye İş Bankası Kültür Yayınları, 2019.

Şeşen, Ramazan, "Belgrad Divanı Tercümanı Osman B. Abdülmennan ve Tercüme Faaliyetindeki Yeri”, İstanbul Üniversitesi Edebiyat Fakültesi Tarih Enstitüsü Dergisi 15 (1995-1997), 302-320.

Tûsî, Nasîruddin, Tahrîru Usûli'l-Hendese ve'l-Hisâb, haz. İhsan Fazlıoğlu, İstanbul: Yazma Eserler Kurumu Yay., 2012.

Üçer, İbrahim Halil (ed.), İslam Düşünce Atlası, Konya: Konya Büyükşehir Belediyesi Kültür Yay., 2017.

Yakıt, İsmail, Türk-İslam Kültüründe Ebced Hesabı ve Tarih Düşürme, İstanbul: Ötüken Yay., 1992. 


\title{
BRIEF HISTORY OF AL-MASAHA AND THE FIRST SEPARATE \\ TURKISH AL-MASAHA BOOK: AMRI CHALABI'S MAJMA'AL- GHARAEB FI AL-MASAHA
}

\begin{abstract}
al-Masaha (science of measuring) is one of the four principal disciplines that are formed as a result of shaping the mathematical accumulation that Islamic Civilization mathematicians inherited from previous civilizations around two basic objects, namely number/al-adad/discontinuous quantity and magnitude/al-miqdar/continuous quantity. While alhisab (arithmetic) and algebra revolve around the number, al-handasa (theoretical geometry) revolves around the magnitude. But al-masaha has a different position in that it concerns both objects. With this characteristic, besides theoretical foundation feeding its own method, it is the main tool of engineering, architecture, urbanism, military technology and various arts with its main principle of "calculating by measuring".
\end{abstract}

It is certain that the Ottoman Civilization, which took over all the scientific accumulation of Islamic Civilization, also adopted the studies in the field of al-masaha and continued within the framework of its own needs, demands and tendencies. In addition to Arabic, which is the language of science in circulation, mathematics works have emerged in Turkish since the 15th and 16th centuries. According to researches, being the earliest known Turkish book that is written entirely on al-masaha Majma'al-Gharaeb fi al-Masaha, is the subject of this article due to this feature. However, in order to provide a background before the introduction of the work, the Ottoman mathematical tradition in general and the al-masaha tradition in particular has been summarized. In this article, historical and mathematical analysis method was used for the presentation of the book. In this article, it is aimed to contribute to the studies of the history of mathematics in the Ottoman civilization by determining al-masaha level of the period in, as well as because of it is the first Turkish book in this field, it will be a source for Turkish language studies.

Keywords: Ottoman, mathematics, al-masaha, applied geometry, Amri Chalabi 
